\title{
FRAMEWORK COBIT 4.1 \\ UNTUK AUDIT SISTEM INFORMASI \\ PADA PERWAKILAN BADAN KEPENDUDUKAN \\ DAN KELUARGA BERENCANA NASIONAL (BKKBN) \\ PROVINSI ABCD
}

Indah Hartati, S.Kom., M.T.I.

Program Studi Sistem Informasi, Sekolah Tinggi Manajemen Informatika dan Komputer (STMIK)

Mitra Lampung

Jl. Zainal Abidin Pagar Alam No.07 Gedung Meneng Rajabasa Bandar Lampung 35145, Indonesia.

e-mail : indah_hartati@umitra.ac.id., kareena_indah@yahoo.co.id

\section{ABSTRACT}

Agency 's National Population and Family Planning (BKKBN) ABCD Province (BKKBN) has the main task to prepare a national plan policies sceara comprehensive and integrated so as to realize a happy little family welfare by limiting the number of births and spacing pregnancies by making family planning. At this time there is no information system audit in Sub Section Equipment and Supplies, especially on the level of service performance measurement procurement, maintenance, care and borrowing that can meet the needs of the organization, so that institutions do not yet know with certainty the existence of problems in the procurement of services, maintenance, maintenance must be addressed. Performance measurement refers to the standard COBIT 4.1 framework on Domain DS1, DS10 and DS12.

Key Performance Indicator (KPI) DS 01 that must be implemented are: Increased operational services to the user continuously. Review agreements and contracts every 1 week in order to stay updated information systems technology. Key Performance Indicator (KPI) DS10 that must be implemented are: Training/training to address the issues/problems that are routinely encountered has been done faithfully 3 (three) months. DS12 implemented Key Performance Indicators monitoring the use of the assets given, supervision of the use of formal facilities, evaluation/monitoring.

The results obtained conclusions, the DS1, DS10 and DS12 on Domain Delivery and Service are supplied by the Sub-Section Equipment and Supplies to the BKKBN ABCD Province in general are defined at the level of process maturity, there is evidence that the institution is aware of the problems that must be addressed, and have been processed using methods that have been standardized in the solution, has clearly defined the steps that will be used to support the service . In general, the approach to the management of the process has been well organized.

Keywords : COBIT 4.1 Framework, Information Systems Auditing, BKKBN 


\begin{abstract}
ABSTRAK
Badan Kependudukan dan Keluarga Berencana Nasioal (BKKBN) Provinsi ABCD mempunyai tugas pokok menyiapkan kebijakan rencana nasional sceara menyeluruh dan terpadu sehingga mewujudkan keluarga kecil bahagia sejahtera dengan membatasi angka kelahiran dan mengatur jarak kehamilan dengan melakukan Keluarga Berencana. Pada saat ini belum ada audit sistem informasi di Sub Bagian Perlengkapan dan Perbekalan terutama mengenai tingkat pengukuran kinerja layanan pengadaan, pemeliharaan, perawatan serta peminjaman yang dapat memenuhi kebutuhan organisasi, sehingga institusi belum mengetahui secara pasti adanya permasalahan di dalam layanan pengadaan, pemeliharaan, perawatan yang harus diatasi. Pengukuran kinerja dilakukan mengacu pada standar frameWork Cobit 4.1 pada Domain DS1, DS10 dan DS12.
\end{abstract}

Key Performance Indicator (KPI) DS 01 yang harus dilaksanakan yaitu : Peningkatan layanan operasional kepada user secara kontinyu, Review perjanjian dan kontrak setiap 1 minggu agar teknologi sistem informasi tetap update. Key Performance Indicator (KPI) DS10 yang harus dilaksanakan yaitu : Training/pelatihan untuk mengatasi masalah/problem yang sering dihadapi telah dilakukan secara rutin setia 3 (tiga) bulan. Key Performance Indicators DS12 dilaksanakan pemantauan penggunaan asset yang diberikan, pengawasan terhadap penggunaan fasilitas secara formal, evaluasi/monitoring.

Hasil penelitian diperoleh simpulan, proses DS1, DS10, dan DS12 pada Domain Delivery and Service yang diberikan oleh Sub Bagian Perlengkapan dan Perbekalan kepada BKKBN Provinsi $\mathrm{ABCD}$ secara umum berada pada tingkat kematangan defined process, yaitu terdapat bukti bahwa institusi mengetahui adanya permasalahan yang harus diatasi, dan telah diproses menggunakan metode yang telah distandarkan dalam penyelesaiannya, telah mendefinisikan dengan jelas langkah-langkah yang akan dipergunakan dalam menunjang pelayanan. Secara umum pendekatan kepada pengelolaan proses telah terorganisasi secara baik.

Kata Kunci : Framework Cobit 4.1, Audit Sistem Informasi, BKKBN 


\section{PENDAHULUAN}

\subsection{Latar Belakang Masalah}

Badan Kependudukan dan Keluarga Berencana Nasioal (BKKBN) Provinsi ABCD (BKKBN) adalah suatu lembaga Non Departemen yang bertanggung jawab langsung kepada Presiden dan mempunyai tugas pokok menyiapkan kebijakan rencana nasional sceara menyeluruh dan terpadu sehingga mewujudkan keluarga kecil bahagia sejahtera dengan membatasi angka kelahiran dan mengatur jarak kehamilan dengan melakukan Keluarga Berencana.

Di dalam organisasi rumah tangganya, Perwakilan BKKBN Provinsi ABCD tidak terlepas dari adanya perlengkapan dan perbekalan yang dibutuhkan untuk mencapai tujuan seperti yang tersebut di atas. Hal ini yang mengharuskan adanya layanan pengadaan, pemeliharaan, perawatan serta peminjaman asset di Sub Bagian Perlengkapan dan Perbekalan yang merupakan salah satu cara yang dapat dipergunakan untuk mencapai tujuan dari BKKBN tersebut.

Sehubungan dengan semakin meningkatnya kegiatan dari Perwakilan BKKBN Provinsi $A B C D$ dalam hal kegiatan informasi mengenai Keluarga Berencana, kebutuhan adanya perlengkapan dan perbekalan di Perwakilan BKKBN Provinsi ABCD mengalami peningkatan (growing trend), selain itu juga terdapat peningkatan kebutuhan (growing demand) dari para penduduk dalam hal ini para penduduk yang menginginkan informasi mengenai keluarga berencana, untuk diberikan pelayanan informasi lebih cepat dan lebih baik.

Pada saat ini terdapat 33 (tiga puluh tiga) perwakilan BKKBN di seluruh Indonesia. Ini merupakan tantangan tersendiri bagi Perwakilan BKKBN Provinsi ABCD agar menjadi organisasi kependudukan yang terpilih di Propinsi ABCD khususnya, Indonesia pada umumnya.

Pelayanan dapat optimal apabila didukuno oleh sistem informasi yang baik dan mar. memberikan respon yang cepat, hal itt yang mengharuskan Sub Bą
Perlengkapan dan Perbekalan Perwakilan BKKBN Provinsi ABCD memiliki sistem informasi yang baik. Pada saat ini belum ada audit sistem informasi di Sub Bagian Perlengkapan dan Perbekalan terutama mengenai tingkat pengukuran kinerja layanan pengadaan, pemeliharaan, perawatan serta peminjaman yang dapat memenuhi kebutuhan organisasi, sehingga institusi belum mengetahui secara pasti adanya permasalahan di dalam layanan pengadaan, pemeliharaan, perawatan yang harus diatasi, dan apakah layanan pengadaan, pemeliharaan, perawatan tersebut telah diproses menggunakan metode yang telah distandarkan dalam penyelesaiannya? serta apakah telah didefinisikan dengan jelas langkah-langkah yang akan dipergunakan dalam menunjang pelayanan?, apakah semua proses tersebut tersebut telah terorganisasi secara baik?.

Memperhatikan uraian di atas maka perlu dilakukan pengukuran dan perhitungan untuk menentukan posisi saat ini dan akan dicari solusi apa yang akan diambil, untuk itu diperlukan alat analisis data yang diperoleh.

Berdasarkan uraian diatas maka diperlukan audit sistem informasi Sub Bagian Perlengkapan dan Perbekalan Perwakilan BKKBN Provinsi ABCD menggunakan frame Work COBIT 4.1.

\subsection{Batasan Masalah}

Dalam penelitian ini permasalahan yang dibahas meliputi :

1. Lokasi penelitian dilakukan di Sub Bagian Perlengkapan dan Perbekalan Perwakilan BKKBN Provinsi ABCD dengan dibatasi permasalahan pada layanan pengadaan, pemeliharaan, perawatan serta peminjaman asset.

2. Pengukuran kinerja dilakukan mengacu pada standar frameWork Cobit 4.1 pada Domain DS1, DS10 dan DS12

a) DS1, mendifinisikan dan mengelola tingat layanan pengadaan, pemeliharaan, perawatan serta peminjaman asset yang memenuhi kebutuhan organisasi dan untuk membangun pemahaman umum 
dari tingkat layanan yang diperlukan

b) DS10, menyelesaikan/mengelola masalah-masalah yang timbul dari pengadaan, pemeliharaan, perawatan serta peminjaman asset dan memastikan bahwa masalahmasalah yang datang dapat diselesaikan dan penyebabnya diselidiki untuk mencegah terulangnya kejadian.

c) DS12, mengelola fasilitas layanan pengadaan, pemeliharaan, perawatan serta peminjaman yang memenuhi kebutuhan bisnis dan memberikan perlindungan kepada peralatan terhadapn bahaya.

\subsection{Ruang Lingkup Masalah}

Penelitian ini meliputi audit sistem informasi pada Sub Bagian Perlengkapan dan Perbekalan Perwakilan BKKBN Provinsi $\mathrm{ABCD}$, pada proses layanan pengadaan, pemeliharaan, perawatan serta peminjaman pada Sub Bagian Perlengkapan dan Perbekalan.

\subsection{Tujuan dan Manfaat Penelitian}

\subsubsection{Tujuan Penelitian}

Tujuan yang hendak dicapai dari penelitian ini ialah sebagai berikut :

1. Menganalisa current dan expected maturity level,

2. Menganalisa gap antara current dan expected maturity level

3. Membuat rekomendasi perbaikan terhadap pelayanan pengadaan, pemeliharaan, perawatan serta peminjaman asset.

\subsubsection{Manfaat Penelitian}

Manfaat yang ingin dicapai dari Tesis ini adalah :

1. Mengetahui current dan expected maturity level, serta gap antara current dan expected maturity level pada proses pelayanan pengadaan, pemeliharaan, perawatan serta peminjaman asset.
2. Rekomendasi yang dihasilkan diharapkan dapat dijadikan acuan perbaikan kualitas layanan pada Sub Bagian Perlengkapan dan Perbekalan Perwakilan BKKBN Provinsi ABCD pada proses pelayanan pengadaan, pemeliharaan, perawatan serta peminjaman asset.

\section{LANDASAN TEORI}

\subsection{Teori-teori Sistem Informasi}

\subsubsection{Pengertian Sistem}

Menurut Mulyadi (diterjemahkan oleh Devi Fitriasari dan Deny Arnos Kwary, 2002), sistem adalah suatu jaringan prosedur yang dibuat menurut pola yang terpadu untuk melaksanakan kegiatan pokok perusahaan.

Menurut James A. O'Brien ( diterjemahkan Devi Fitriasari dan Deny Arnos Kwary, 2005), sistem adalah sekelompok komponen yang saling berhubungan, bekerja sama untuk mencapai tujuan bersama dengan menerima input serta menghasilkan output dalam proses transformasi yang teratur.

Menurut Tata Sutabri (2004), suatu sistem pada dasarnya adalah sekelompok unsur yang erat hubungannya satu dengan yang lain, yang berfungsi bersama - sama untuk mencapai tujuan tertentu.

Jadi dapat disimpulkan bahwa sistem adalah kumpulan dari beberapa elemen yang saling berhubungan atau berinteraksi untuk mencapai satu tujuan dan terintegrasi.

\subsubsection{Pengertian Informasi}

Menurut Jeffery L.Whitten, Lonnie D. Bentley dan Kevin C. Dittman ( diterjemahkan oleh Ardi, 2004), informasi adalah data yang telah diproses atau diorganisasi ulang menjadi bentuk yang berarti. Informasi dibentuk dari kombinasi yang diharapkan memiliki arti ke penerima.

Menurut James A. O'Brien ( diterjemahkan oleh Devi Fitriasari dan Deny Arnos Kwary, 2005), informasi adalah data yang telah 
diubah menjadi kontek yang berarti dan berguna bagi para pemakai akhir tertentu.

Menurut George H.Bonar dan William S.Hopwood (diterjemahkan oleh Amir Abadi Jusuf dan Rudi M.Tambunan, 2000), informasi adalah data yang berguna yang diolah sehingga dapat dijadikan dasar untuk mengambi keputusan yang tepat.

Menurut Turban Rainer Potter (2003), "Information is a collection of fact (data) organized in some manner so that they are meaningful to a recipient". (informasi adalah suatu kumpulan dari fakta ( data ) yang terorganisir dalam beberapa cara sedemikian rupa sehingga mereka penuh arti bagi seorang penerima.

Jadi dapat disimpulkan bahwa informasi adalah data yang sudah diolah yang mempunyai arti khusus dan dapat digunakan sebagai bahan pengambilan keputusan.

\subsubsection{Pengertian Sistem Informasi}

Menurut Jeffery L.Whitten, Lonnie D. Bentley dan Kevin C. Dittman (diterjemahkan oleh Andi, 2004), sistem informasi adalah pengaturan, orang, data, proses, dan teknologi informasi yang berinteraksi untuk mengumpulkan, memproses, menyimpan, dan menyediakan sebagai output informasi yang diperlukan untuk mendukung sebuah organisasi.

Menurut James A. O'Brien ( diterjemahkan oleh Devi Fitriasari dan Deny Arnos Kwary, 2005), sistem informasi adalah sistem yang menerima sumberdaya ( data ) sebagai input dan memprosesnya menjadi produk ( informasi ) sebagai outputnya.

Menurut Turban Rainer Potter (2003), “ An information system (IS ) collects, processes, stores, analyzes, and disseminates information for a specific purpose ". (Suatu sistem informasi (SI ) mengumpulkan, memproses, menyimpan, meneliti, dan menyebarkan informasi untuk suatu tujuan yang spesifik ).

Jadi dapat disimpulkan bahwa sistem informasi adalah suatu kerangka kerja dimana sumberdaya (man, machine, material, money, information) dikoordinasikan untuk mengubah input ( data sumberdaya ) menjadi output ( informasi barang jadi ) guna mencapai sasaran - sasaran perusahaan.

\subsection{Konsep Audit}

\subsubsection{Pengertian Audit}

Menurut A.Arens dan James K.Loebbeck (2001), audit adalah proses sistematis untuk menghimpun dan mengevaluasi bukti-bukti secara obyektif mengenai asersi-asersi tentang berbagai tindakan dan kejadian ekonomi untuk menentukan tingkat kesesuaian antara asersi-asersi tersebut dengan kriteria yang telah ditentukan dan menyampaikan hasilnya kepada para pemakai yang berkepentingan.

Selanjutnya menurut A.Arens dan James K.Loebbecke (2001) dalam bukunya yang diterjemahkan oleh Amir Abadi Jusuf, “ Auditing adalah proses pengumpulan dan pengevaluasian bahan bukti berupa informasi yang dapat diukur mengenai suatu entitas ekonomi yang dilakukan seorang yang kompeten dan independen untuk dapat menentukan dan melaporkan kesesuaian informasi dimaksud dengan kriteria kriteria yang telah ditetapkan.

Menurut James Hall (2001) dalam bukunya yang diterjemahkan oleh Jusuf,

Auditing adalah salah satu bentuk pengujian independen yang dilakukan oleh seorang ahli yang menunjukkan pendapatnya tentang kejujuran ( fairness ) sebuah laporan keuangan.

Menurut A.Arens dan James K.Loebbecke (2003) "Auditing is the accumulation and evaluation of evidence about information to determine and report on the degree of correspondence between the information and established criteria. Auditing should be done by a competent, independent person". ( Auditing adalah proses pengumpulan dan penilaian bahan bukti tentang informasi untuk menentukan dan melaporkan kesesuaian informasi dengan kriteria kriteria yang telah ditetapkan dan dilakukan oleh orang yang kompeten dan independen ) 
Jadi dapat disimpulkan bahwa audit adalah suatu sistem yang digunakan untuk melakukan pemeriksaan terhadap empat laporan keuangan ( neraca, arus kas, perubahan modal dan rugi/laba), apakah laporan keuangan tersebut wajar menurut prinsip - prinsip dasar akuntansi dan mengevaluasi bukti - bukti audit.

\subsubsection{Jenis - Jenis Audit}

Menurut Arens dan Loebbecke (2001), ada tiga jenis audit, yaitu:

a. Audit Laporan Keuangan ( General Financial Statement Audit )

Audit laporan keuangan bertujuan untuk menentukan apakah laporan keuangan secara keseluruhan yang merupakan informasi terukur yang akan diverifikasikan telah disajikan sesuai dengan kriteria-kriteria tertentu.

b. Audit Operasional atau Manajemen ( Operational or Management Audit) Audit operasional merupakan penelaahan atas bagian manapun dari prosedur dan metode operasi suatu organisasi untuk menilai efisiensi dan efektivitasnya. Umumnya, pada saat selesainya audit operasional, auditor akan memberikan sejumlah saran kepada manajemen untuk memperbaiki jalannya operasi perusahaan.

c. Audit Ketaatan (Compliance Audit) Audit ketaatan bertujuan mempertimbangkan apakah klien telah mengikuti prosedur atau aturan tertentu yang telah ditetapkan pihak yang memiliki otorisasi lebih tinggi, misalnya pemeriksaan surat perjanjian dengan banyak dan atau kreditur lain untuk memastikan bahwa perusahaan tersebut telah memenuhi ketentuan hukum yang berlaku.

\subsubsection{Instrumen Audit}

Menurut Weber, R (2001), instrumen audit yang digunakan untuk mengumpulkan data adalah sebagai berikut :

a. Wawancara

Dalam audit, auditor menggunakan teknik interview atau wawancara dengan beberapa alasan, yaitu:
1. Sistem analisa dan programmer yang mendesain dan mengimplementasikan sistem aplikasi dapat diwawancarai sehingga auditor lebih mengerti akan fungsi dan kontrol sistem .

2. User juga dapat di wawancarai untuk menjelaskan seberapa besar kualitas dari sistem yang mereka gunakan.

3. Pengendalian organisasi dapat di wawancarai untuk mengidentifikasinya sistem yang kritis yang terdapat dalam organisasi .

b. Check list

Adalah membuat daftar pertanyaan yang ditujukan kepada pihak yang terkait diperusahaan, khususnya bagian penjualan untuk mengetahui kondisi yang sebenarnya.

c. Observasi

Adalah memeriksa dengan menggunakan panca indera terutama mata, yang dilakukan secara berulang ulang selama kurun waktu tertentu untuk membuktikan sesuatu keadaan atau masalah.

\subsubsection{Audit Sistem Informasi}

\subsubsection{Pengertian Audit Sistem Informasi}

Menurut Weber, R. (2001), " Information systems auditing is the process of collecting and evaluating evidence to determine whether a Computer system safeguards assets, maintains data integrity, allows organizational goals to be achieved effectively, and users resources efficiently." (Audit sistem informasi adalah proses pengumpulan dan pengevaluasian bukti - bukti untuk menentukan apakah sistem aplikasi komputerisasi telah menetapkan dan menerapkan sistem pengendalian intern yang memadai, semua aktiva dilindungi dengan baik untuk menjamin integritas data, kehandalan serta efektifitas dan efisiensi penyelenggaraan sistem informasi berbasis komputer tersebut ) . 


\subsubsection{Tujuan Audit Sistem Informasi}

Menurut Ron Weber (2001), tujuan audit sistem informasi dapat dibagi menjadi empat, yaitu ;

a. Meningkatkan keamanan asset perusahaan

Asset suatu peusahaan seperti perangkat keras ( hardware), perangkat lunak ( software), sumber daya manusia, dan file data harus mempunyai sistem pengendalian intern yang baik agar tidak terjadi penyalahgunaan asset perusahaan.

b. Meningkatkan integritas data Integritas data adalah suatu konsep dasar yang sistem informasi. Data memiliki atribut - atribut tertentu seperti kelengkapan, kebenaran, dan keakuratan. Jika integritas data tidak terpelihara maka suatu perusahaan tidak akan memiliki laporan yang benar bahkan perusahaan dapat menderita kerugian.

c. Meningkatkan efektifitas sistem

Efektifitas sistem informasi perusahaan memiliki peranan dalam pengambilan keputusan. Suatu sistem informasi dapat dikatakan efektif apabila suatu sistem sudah sesuai dengan kebutuhan user.

d. Meningkatkan efisiensi

Suatu sistem dapat dikatakan efisien jika sistem informasi dapat memenuhi kebutuhan user dengan sumber daya informasi minimal.

\subsubsection{Perlunya Pengendalian dan Audit Sistem Informasi}

Faktor-faktor yang mendorong pentingnya pengendalian dan audit sistem informasi menurut Ron Weber (2001) adalah untuk :

a. Mendeteksi agar komputer tidak dikelola secara kurang terarah, tidak ada visi, misi, perencanaan sistem informasi pimpinan tertinggi organisasi kurang peduli, tidak ada pelatihan dan pola karir personal yang baik, dan sebagainya.

b. Mendeteksi resiko kehilangan data.

c. Mendeteksi resiko pengambilan keputusan yang salah akibat informasi hasil proses sistem komputerisasi yang salah atau tidak lengkap. d. Menjaga asset perusahaan karena nilai hardware, software, dan personil yang lazimnya tinggi.

e. Mendeteksi error komputer.

f. Menjaga kerahasiaan, maksudnya adalah bahwa sistem informasi berbasis komputer hendaknya mempunyai kemampuan untuk memproteksi aman, terjaganya privasi para penggunanya dan sebagainya.

g. Mendeteksi resiko penyalahgunaan komputer.

\subsubsection{Jenis - jenis Audit Sistem Informasi}

Menurut Weber, R. (2001), jenis - jenis audit sistem informasi adalah sebagai berikut :

a. Audit secara bersamaan

Concurrent Audit )

Auditor merupakan anggota dari tim pengembangan sistem, mereka membantu tim dalam meningkatkan kualitas dan pengembangan untuk sistem spesifikasi yang mereka bangun dan akan diimplementasikan.

b. Audit setelah implementasi

Post Implementation Audit )

Auditor membantu organisasi untuk belajar dari pengalaman pengembangan dari sistem aplikasi. Mereka mengevaluasi apakah sistem perlu dihentikan, dilanjutkan atau di modifikasi.

c. Audit Umum ( General Audit )

Auditor mengevaluasi kontrol pengembangan sistem secara keseluruhan, memberi opini audit tentang pernyataan keuangan ataupun tentang keefektifitasan dan keefisienan sistem.

\subsubsection{Tahapan Audit}

Menurut Ron Weber (2001), tahapan audit sistem informasi dibagi menjadi lima tahapan, antara lain :

a. Perencanaan audit (Planning the Audit) Perencanaan adalah tahap awal. Pada tahap ini auditor harus menentukan tingkat preliminary material untuk audit serta mencoba memperoleh pengertian 
mengenai pengendalian intern yang digunakan dalam organisasi.

b. Pengujian pengendalian ( Test of Control)

Auditor harus melakukan pengujian atas pengendalian tertentu untuk mengevaluasi apakah mereka beroperasi secara efektif.

c. Pengujian transaksi ( Test of Transactions )

Auditor menjalankan pengujian substantive untuk mengevaluasi apakah ada kesalahan material atau salah penyajian dari akuntansi yang terjadi ataupun yang mungkin terjadi.

d. Pengujian balanced atau hasil keseluruhan ( Tests of Balances or Everall results) Auditor mencari untuk mendapatkan bukti yang cukup untuk membuat keputusan akhir tingkat kesalahan atau salah penyajian yang telah tejadi atau yang mungkin terjadi.

e. Penyelesaian audit (Completion of the audit )

Auditor memberi opini apakah ada kesalahan material ataupun salah penyajian yang telah terjadi ataupun yang mungkin terjadi.

\subsubsection{Standar Audit}

Menurut Information System Audit and Control Association (ISACA), Standar Audit adalah sebagai berikut :

a. S1 - Audit Charter

1. Tujuan, tanggungjawab, otorisasi, dan akuntabilitas fungsi audit SI pada suatu organisasi / perusahaan ataupun penguasa audit harus dengan dibuat tertulis ( didokumentasikan ) dalam audit charter atau engagement letter.

2. Audit Charter atau engagement letter harus disetujui dan ditandatangani oleh pimpinan organisasi.

\section{b. S2 - Independence}

1. Independensi Professional Dalam segala hal yang berkaitan dengan audit, auditor harus independen dalam sikap dan penampilan.

2. Independensi Organisasi
Fungsi audit SI harus bebas ( tidak ada conflict of interest ) dari area yang diperiksa untuk dapat menyelesaikan tugas audit dengan baik.

\section{c. S3 - Professional Ethics Standards}

1. Code of Professional Ethics

Auditor dari sistem informasi harus menghormati dan menaati etika profesional dari Information System Audit and Control Association.

2. Due Professional Care

Standards auditing Professional harus diterapkan dalam segala aspek dalam pekerjaan yang dilakukan oleh auditor sistem informasi.

\section{d. S4 - Professional Competence}

1. Auditor SI harus mampu secara profesional, mempunyai pengetahuan dan keahlian teknis untuk melakukan penugasan tugas audit.

2. Auditor SI harus memelihara kemampuan profesionalnya dengan pendidikan dan pelatihan berkelanjutan.

e. S5 - Audit Planning

1. Auditor SI harus membuat rencana kerja audit SI, mencakup tujuan audit, dan bahwa kegiatan kegiatan auditnya akan sesuai dengan aturan, hukum dan standar Professional audit yang ada.

2. Auditor SI harus melakukan teknik pendekatan audit berbasis resiko ( risks - based audit ) dan mendokumentasikannya dengan baik.

3. Auditor SI harus menyusun rencana kerja audit, mencakup rincian tentang hakekat dan tujuan audit, periode atau waktu yang diperlukan, dan sumber daya yang diperlukan untuk penugasan audit tersebut.

4. Auditor SI harus menyusun rencana kerja audit dan / atau program audit, mencakup prosedur audit yang diperlukan untuk penyelesaian tugas audit itu. 
f. S6 - Performance of Audit Work

1. Supervisi
a. Staff audit SI harus disupervisi untuk memperoleh keyakinan memadai bahwa tujuan audit yang telah dicapai sesuai dengan standar profesional audit.

2. Bukti audit

a. Dalam pelaksanaan tugasnya auditor SI harus memperoleh bukti yang cukup, reliable, dan relevan untuk pencapaian tujuan audit. Temuan hasil audit harus didasarkan pada ketersediaan bukti yang cukup, dianalisis dan di interprestasikan / dievaluasi dengan baik / tepat.

3. Dokumentasi

$$
\begin{aligned}
& \text { a. Proses audit harus } \\
& \text { didokumentasikan, } \\
& \text { menjelaskan pelaksanaan } \\
& \text { kegiatan audit, dan bukti audit } \\
& \text { yang mendukung kesimpulan } \\
& \text { / temuan audit. }
\end{aligned}
$$

g. S7 - Reporting

1. Auditor SI harus membuat laporan hasil audit dalam format yang tepat segera setelah selesai melakukan tugas auditnya. Laporan hasil audit harus memuat organisasi, pihak yang dituju, dan batasan - batasan sirkulasi ( jika ada ).

2. Laporan audit harus menyebutkan ruang - lingkup, tujuan periode dan waktu pelaksanaan pemeriksaan.

3. Laporan audit harus berisi temuan, kesimpulan dan rekomendasi, serta pengungkapan mengenai penyediaan, kualifikasi atau pembatasan cakupan audit yang dialami oleh auditor SI dalam melaksanakan tugasnya.

4. Temuan hasil audit yang dilaporkan harus didukung bukti audit yang cukup, lengkap dan kompeten untuk mendukung laporan hasil pemeriksaan itu.
5. Laporan hasil audit harus ditandatangani, dibubuhi tanggal pelaporan, dan didistribusikan sesuai ketentuan pada audit charter / letter of engagement.

h. S8 - Follow Up Activities

1. Setelah laporan hasil audit yang mengemukakan temuan dan rekomendasi, auditor SI harus mengevaluasi informasi yang relevan untuk memperoleh keyakinan apakah tindak - lanjut yang diperlukan (atas rekomendasi) telah dilaksanakan oleh pihak manajemen sesuai jadwal yang diusulkan ( tepat waktu ).

i. $\quad$ S9-Irregularities of Audit Work

1. Dalam perencanaan dan pelaksanaan audit untuk mengurangi resiko audit, auditor SI harus mempertimbangkan resiko ketidakteraturan dan illegal acts.

2. Auditor SI harus bersikap profesional skeptis dalam pelaksanaan audit, $\mathrm{p}$ aham kemungkinan misstatements yang material dapat saja terjadi karena adanya irregularities dan illegal acts, di luar evaluasi yang telah dilakukan.

3. Auditor SI harus memahami organisasi dan lingkungannya, termasuk sistem pengendalian internal bidang yang diperiksa.

4. Auditor SI harus memiliki bukti audit yang lengkap dan kompeten untuk menentukan apakah manajemen atau pihak lainnya dalam organisasi mengetahui aktual, curiga atau yang diduga keras terdapat ketidakteraturan dan / atau tindakan - tindakan yang ilegal.

5. Dalam menjalankan prosedur audit untuk memahami organisasi dan lingkungannya, auditor SI harus dapat mempertimbangkan kemungkinan hubungan tak terduga atau bisa terjadinya resiko misstatemens akibat ketidakteraturan dan / atau tindakan - tindakan ilegal. 
6. Auditor SI harus merancang dan menjalankan prosedur untuk menguji ( test ) kecukupan pengendalian intern dan resiko manajemen mengesampingkan pengendalian intern.

7. Jika auditor SI mengidentifikasikan adanya misstatements, auditor SI harus menilai apakah misstatements tersebut terjadi akibat irregularities dan illegal acts, jika ya, auditor SI harus memikirkan kemungkinan dampaknya ke bidang lain, khususnya berkaitan dengan representations of management.

8. Auditor SI harus memperoleh representasi tertulis dari manajemen, dilakukan sedikitnya setiap tahun atau lebih sering lagi bergantung pada penugasan audit yang antara lain :

9. Pengakuan tanggungjawab manajemen untuk merancang dan mengimplementasikan kontrol internal untuk mencegah dan mendeteksi irregularities dan illegal acts.

10. Mengungkapkan kepada auditor mengenai penilaian resiko jika terdapat kemungkinan misstatements yang material sebagai akibat irregularities dan illegal acts.

11. Mengungkapkan kepada auditor tentang pengetahuannya terhadap rregularities dan illegal acts, dampaknya kepada organisasi dan kaitannya dengan manajemen maupun karyawan yang mempunyai peran penting dalam sistem pengendalian intern.

12. Mengungkapkan kepada auditor jika mengetahui atau menduga adanya irregularities dan illegal acts atau disampikan oleh karyawan, eks karyawan, pihak regulator atau yang lain.

13. Jika auditor SI mengidentifikasikan adanya irregularities dan illegal acts atau memperoleh informasi mengenai hal itu, auditor harus mengkomunikasikan ini kepada level manajemen yang tepat sesegera mungkin.

14. Jika auditor SI mengidentifikasikan irregularities dan illegal acts yang melibatkan manajemen atau personil yang berperan dalam internal control, auditor intern harus mengkomunikasikan hal itu kepada pihak yang bertanggungjawab dalam tatakelola perusahaan.

15. Auditor SI harus memberi advice kepada tingkat manajemen yang bertanggungjawab atas kelemahan rancangan dan implementasi internal control dalam mencegah dan mendeteksi irregularities dan illegal acts yang mendapat perhatian auditor dalam melaksanakan penugasan pemeriksaannya.

16. Jika auditor SI menemui kondisi yang tidak biasa yang berdampak pada kelanjutan pelaksanaan audit sebagai akibat misstatements yang material dan / atau tindakan ilegal, auditor harus mempertimbangkan tanggungjawab legal dan profesional, termasuk kemungkinan auditor untuk memberitahu kepada pihak - pihak ( lain ) yang mendapat penugasan, penanggungjawab perusahaan, atau pihak berwenang, dan bila perlu mengundurkan diri dari penugasan.

17. Auditor SI harus mendokumentasikan semua komunikasi, perencanaan, hasil, evaluasi, dan kesimpulan yang berhubungan dengan irregularities dan illegal acts yang sudah dikomunikasikan kepada manajemen, pihak bertanggungjawab lain, atau pihak berwenang, dan lainnya.

\section{j. S10-IT Governance}

1. Auditor SI harus melakukan peninjauan dan penilaian apakah fungsi SI sudah selaras dengan visi, misi, tata - nilai, dan strategis serta tujuan organisasi. 
2. Auditor SI melakukan peninjauan apakah fungsi SI memiliki pernyataan yang jelas mengenai kinerja yang diharapkan oleh organisasi ( efektif dan efisien ) dan dinilai apakah hal -hal tersebut sudah tercapai.

3. Auditor SI harus meninjau dan menilai efektivitas sumberdaya SI dan kinerja proses manajemennya.

4. Auditor SI harus meninjau dan menilai kepatuhan terhadap legal, lingkungan dan kualitas informasi, dan keamanan.

5. Dalam pemeriksaan dan evaluasi fungsi SI, auditor sebaiknya menggunakan pendekatan audit berbasis resiko ( risk - based audit approach ).

6. Auditor SI harus meninjau dan menilai lingkungan pengendalian auditan.

7. Auditor SI harus meninjau dan menilai resiko yang mungkin terjadi dalam lingkungan sistem berbasis teknologi informasi.

\subsubsection{Teknik dan praktek Audit Sistem Informasi}

Menurut Gondodiyoto (2007), dalam melakukan audit system informasi dapat dilakukan dengan tiga pendekatan :

a. Audit disekitar Computer (Audit Around The Computer)

Dalam pendekatan ini, auditor dapat melangkah pada perumusan pendapat hanya dengan menelaah struktur pengendalian dan melakukan pengujian transaksi dan persedur verifikasi saldo perkiraan dengan cara sama seperti pada system manual (bukan system informasi berbasis Computer). Auditor tidak perlu menguji pengendalian system informasi berbasis Computer klien (yaitu terhadap file program/data didalam Computer), melainkan cukup terhadap input dan output system aplikasi saja.

Keunggulan mengunakan pendekatan ini adalah :

1. Pelaksanaan auditnya lebih sederhana.

2. Auditor yang memiliki pengetahuan minimal dibidang
Computer dapat dilatih dengan mudah untuk melaksanakan audit.

Kelemahannya adalah jika lingkungan berubah, kemungkinan system itu akan berubah dan perlu penyesuaian system atau program - programnya, bahkan mungkin struktur data atau file, sehingga auditor tidak dapat menilai atau menelaah apakah system masih berjalan dengan baik.

b. Audit melalui Computer (Audit Through The Computer)

Dalam pendekatan ini, auditor melalukan pemeriksaan langsung terhadap program - program dan file Computer yang ada pada audit system informasi berbasis Computer. Auditor menggunakan bantuan software Computer langsung atau dengan cek logika atau listing program untuk menguji logika program dalam rangka pengujian pengendalian yang ada dalam kompter. Selain itu, auditor juga dapat memintak penjelasan dari para teknisi Computer mengenai spesifikasi system dan program yang diperiksanya.

Keunggulan menggunakan pendekatan ini adalah :

1. Auditor dapat menilai kemapuan system Computer tersebut untuk menghadapi perubahan lingkungan.

2. Auditor memperoleh kemampuan yangbesar dan efektif dalam melakukan pengujian terhadap system Computer.

3. Auditor akan merasa lebih yakin terhadap kebenaran hasil kerjanya. Kelemnahannya adalah pendekatan ini memerlukan biaya yang besar dan memerlukan tenaga ahli yang terampil.

c. Audit dengan Computer (Audit with The Computer)

Pendekatan ini dilakuan dengan menggunakan Computer dan software untuk mengotomatisasi prosedur pelaksanaan audit. Pendekatan ini merupakan cara audit yang sangat bermanfaat, khususnya dalam 
pengujian substantif atas file dan record perusahaan. Software audit yang diguanakan merupakan program Computer auditor untuk membantu dalam pengujian dan evaluasi kehandalan data, file atau record perusahaan.

Keunggulan menggunakan pendekatan ini adalah:

1. Merupakan program Computer yang diproses untuk membantu pengujian pengendalian system Computer klien itu sendiri.

2. Dapat melaksanakan tugas audit yang terpisah dari catatan klien, yaitu dengan mengambil copy data atau file untuk dites dengan Computer lain. Kelemahan adalah upaya dan biaya untuk pengembangan relatif besar

\subsubsection{Prosedur Audit $\quad$ Sistem Informasi}

Menurut Weber (2001), tahapan - tahapan audit system informasi terdiri dari :

a. Merupakan tahapan pertama dalam audit bagi auditor eksternal yang berarti menyelidiki dari awal atau melanjutkan yang ada untuk menentukan apakah pemeriksaan tersebut dapat diterima, penempatan staf audit yang sesuai melakukan pengecekan informasi latar belakang klien, mengerti kewajiban utama dari klien dan mengidentifikasi area resiko.

b. Pengujian atas control (Tests of Controls)

Tahap ini dimulai dengan pemfokusan pada pengendalian menejemen, apabila hasil yang ada tidak sesuai dengan harapan, maka pengendalian menejemen tidak berjalan sebagai mana mestinya. Bila auditor menemukan kesalahan yang serius pada pengendalian menejemen, maka mereka akan mengemukakan opini atau mengambil keputusan dalam pengujian transaksi dan saldo untuk hasilnya.

c. Pengujian atas transaksi (Tests of Transaction)

Pengujian yang termasuk adalah pengecekan jurnal yang masuk dari dokumen utama, menguji nilai kekayaan dan ketepatan komputasi. Computer sangat berguna dalam pengujian ini dan auditor dapat menggunakan software audit yang umum untuk mengecek apakah pembayaran bunga dari bank telah dikalkulasi secara tepat.

d. Pengujian atas keseimbangan atau hasil keseluruhan (Tests of Balances or Overall Results)

Auditor melakuan pengujian ini agar bukti penting dalam penilaian akhir kehilangan atau pencatatan yang keliru yang menyebabkan fungsi system informasi gagal dalam memelihara data secara keseluruhan dan mencapai system yang efektif dan efesien. Dengan kata lain, dalam tahap ini mementingkan pengamatan asset dan integritas data yang obyektif.

e. Penyelesaian audit (Completion of The Audit)

Tahap terakhir ini, auditor eksternal melakukan beberapa pengujian tambahan untuk mengkoleksi bukti unutk ditutup, dengan memberikan pernyataan pendapat.

\subsection{COBIT (Control Objektive for information and related Technology)}

COBIT, yaitu Control Objektive for information and related Technology (COBIT) adalah sekumpulan best practice (Praktik terbaik) atau frameWork (kerangka kerja) untuk manajemen IT yang dibuat oleh Information System Audit and control Association (ISACA) dan IT Governance Institute (ITGI). Cobit menyediakan para manajer, auditor dan para pengguna IT sekumpulan pengukuran yang telah diakui secara umum, indicator, proses dan best practices untuk membantu mereka memaksimalkan keuntungan yang diperoleh dari penggunaan teknologi informasi dan juga membantu mengembangkan IT Governance yang tepat (IT Government Institute, 2000)

Menurut IT Governance Institute (ITGI) audit teknologi informasi adalah pengawasan dan pengendalian dari infrastruktur teknologi informasi secara menyeluruh. Audit Teknologi informasi ini dapat berjalan bersama-sama dengan audit 
financial dan audit internal, atau dengan kegiatan pengawasan dan evaluasi lain yang sejenis. Pada mulanya istilah ini dikenal dengan audit pemrosesan data elektronik, dan sekarang audit teknologi informasi secara umum merupakan proses pengumpulan data dan evaluasi dari semua kegiatan system informasi dalam perusahaan itu.

COBIT memiliki misi melakukan riset, mengembangkan, mempublikasikan, dan mempromosikan makalah-makalah, serta meng update tatanan atau ketentuan TI Control objective yang dapat diterima umum (generally accepted control objective) berikut panduan pelengkap yang dikenal sebagai Audit Guidelines yang memungkinkan penerapan FrameWork dan Control objective dapat berjalan mudah. Tatanan atau ketentuan tersebut selanjutnya digunakan oleh para manajer dunia usaha maupun auditor dalam menjalankan profesinya. Sedangkan Visi dari COBIT adalah dijadikan COBIT sendiri sebagai satu-satunya model pengurusan dan pengendalian teknologi informasi (Information Technology Governance).

COBIT dirancang terdiri dari 34 Control objective yang tercermin didalam 4 domain. Berikut adalah 4 domain COBIT, yaitu :

1. Plan and Organise (PO)

2. Acquire and Implement (AI)

3. Delivery and Support (DS)

4. Monitor and Evaluasi (ME)

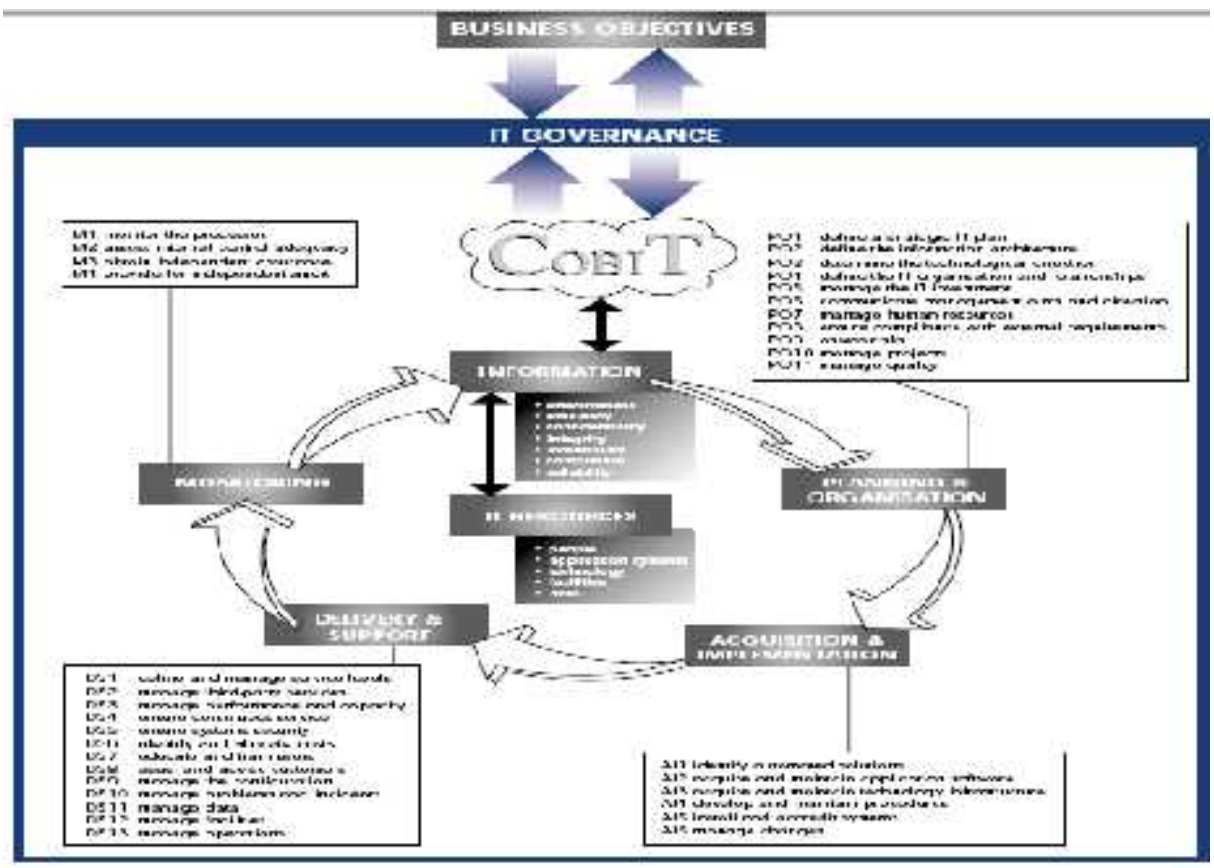

\subsubsection{Delivery and support (Penyampaian dan dukungan /DS)}

Pada Ranah ini berfokus pada aspek hasil keluaran dari IT. Ranah ini meliputi area seperti pengeksekusian aplikasi disalam system IT dan hasilnya, dan juga proses dukungan yang memungkinkan eksekusi system IT yang efektif dan efesien. Proses dukungan ini meliputi pelatihan dan issu keamanan.

Tabel 2.1 Daftar High Level Control Objectives dari Delivery And Support

\begin{tabular}{|l|l|}
\hline DS1 & Mendefinisikan dan Mengelola tingkat layanan \\
\hline DS2 & Mengelola layanan pihak ketiga \\
\hline DS3 & Mengelola kinerja dan kapasitas \\
\hline DS4 & Memastikan layanan yang berkelanjutan \\
\hline DS5 & Memastikan keamanan sistem \\
\hline DS6 & Mengidentifikasi dan mengalokasi biaya \\
\hline
\end{tabular}




\begin{tabular}{|l|l|}
\hline DS7 & Mendidik dan melatih pengguna \\
\hline DS8 & Mengelola Service dan insiden \\
\hline DS9 & Mengelola konfigurasi \\
\hline DS10 & Mengelola Permasalahan \\
\hline DS11 & Mengelola Data \\
\hline DS12 & Mengelola lingkungan fisik \\
\hline DS13 & Mengelola operasi \\
\hline
\end{tabular}

\subsubsection{Plan and Organize (Perencanaan dan Organisasi / PO)}

Ranah ini meliputi penggunaan IT dan bagaimana cara terbaik menggunakannya dalam sebuah perusahaan untuk membantu perusahaan tersebut mencapai tujuannya. Ranah ini juga menekankan bentuk IT
Secara organisasional dan infrastruktur untuk mencapai hasil optimal dan untuk menghasilkan keuntungan terbaik dari pengguna IT. Tabel 1.2. Memperlihatkan daftar high level control objectives dari ranah ini.

Tabel 2.2. High Level Control Objektives dari Plan and Organize

\begin{tabular}{|l|l|}
\hline PO1 & Mendefinisikan rencana strategi TI \\
\hline PO2 & Mendefinisikan arsitektur informasi \\
\hline PO3 & Menentukan arahan teknologi \\
\hline PO4 & Mendefinisikan proses TI, organisasi dan keterhubungan \\
\hline PO5 & Mengelola investasi \\
\hline PO6 & Mengkomunikasikan tujuan dan arahan manajemen \\
\hline PO7 & Mengelola sumber data TI \\
\hline PO8 & Mengelola Kualitas \\
\hline PO9 & Menaksir dan mengelola resiko TI \\
\hline PO10 & Mengelola proyek \\
\hline
\end{tabular}

\subsubsection{Acquire and Implement (Akuisisi dan Implementasi / AI)}

Ranah ini meliputi pengidentifikasian kebutuhan IT, Kepemilikian teknologi, dan implementasinya kedalam proses bisnis perusahaan saat ini. Ranah ini juga ditujukan untuk pengembangan rencana perawatan yang perusahaan harus miliki dengan tujuan memperpanjang system IT dan komponenkomponennya.

Tabel 2.3. Daftar high level control objectives dari ranah ini.

\begin{tabular}{|l|l|}
\hline AI1 & Mengidentifikasi Solusi Otomatis \\
\hline AI2 & Memperoleh dan memelihara perangkat lunak aplikasi \\
\hline AI3 & Memperoleh dan memelihara infrastruktur teknologi \\
\hline AI4 & Memungkinkan operasional dan penggunaan \\
\hline AI5 & Memenuhi Sumber Data TI \\
\hline AI6 & Mengelola Perubahan \\
\hline AI7 & Instalasi dan akreditasi solusi beserta perubahannya \\
\hline
\end{tabular}

kebutuhan relugasi. Monitoring juga terkait dengan issu assessment yang independen

\subsubsection{Monitoring and Evaluate} (Pengawasan dan Evaluasi/ME)

Ranah ini berhubungan dengan strategi perusahaan dalam meng-acces kebutuhan perusahaan dan apakah system IT yang ada saat ini masih memenuhi tujuan desainnya dan control yang dibutuhkan terhadap terhadap keefektifan system IT dalam kemampuan memenuhi tujuan bisnis. Tabel 1.4 memperlihatkan daftar high level objectives dari ranah ini. 
Tabel 2.4. High Level Control Objective dari Monitoring

\begin{tabular}{|l|l|}
\hline ME1 & Mengawasi dan mengevaluasi kinerja TI \\
\hline ME2 & Mengawasi dan mengevaluasi control internal \\
\hline ME3 & Memastikan pemenuhan terhadap kebutuhan eksternal \\
\hline ME4 & Menyediakan tata kelola TI \\
\hline
\end{tabular}

Keempat Domain tersebut dapat pula digambarkan dalam bentuk gambar dibawah ini yang juga terdapat 34 High level objectives dan 6 Publikasi.

Tata kelola TI atau IT (Information Technology) Governance merupakan struktur hubungan dan proses untuk mengarahkan dan mengendalikan organisasi untuk mencapai tujuannya dengan menambahkan nilai ketika menyeimbangkan risiko dibandingkan dengan TI dan prosesnya. Dalam tesis ini akan dihasilkan suatu rekomendasi IT Governance yang merupakan pengembangan dari IT Governance yang dilaksanakan oleh Institusi Perwakilan BKKBN Provins ABCD, Rekomendasi ini dibuat guna meningkatkan kinerga layanan peminjaman Sarana \& Prasarana di Perwakilan BKKBN Provins ABCD dimana aktivitas layanan tersebut menjadi tanggungjawab kerja suatu sub bagian yaitu sub bagian perlengkapandan perbekalan.

\subsubsection{Maturity Models}

COBIT mempunyai model kematangan (maturity models) (5) untuk mengontrol proses-proses TI dengan menggunakan metode penilaian (scoring) sehingga suatu organisasi dapat menilai proses-proses TI yang dimilikinya dari skala dari 0 sampai 5). Maturity model yang ada pada COBIT dapat dilihat pada tabel II.1 berikut ini :

Tabel 2.5 Deskripsi Maturity model COBIT

\begin{tabular}{|c|c|}
\hline P I L I H A N & K R I T E R I A \\
\hline $\begin{array}{l}\text { Level } 0 \\
\text { (Non-existent) }\end{array}$ & Organisasi belum mengenal isu-isu yang berkaitan proses TI. \\
\hline $\begin{array}{l}\text { Level } 1 \\
\text { (Initial) }\end{array}$ & $\begin{array}{l}\text { a. Aktifitas TI telah dikenal dan telah menyadari akan pentingnya } \\
\text { aktifitas tersebut, tetapi belum ada usaha untuk melaksanakannya. } \\
\text { Kalaupun ada hanya hanya bersifat perorangan, tidak konsisten } \\
\text { (perkasus). } \\
\text { b. Tidak ada penilaian yang standard dan monitoring hanya } \\
\text { dilakukan apabila aktifitas TI telah menimbulkan kerugian bagi } \\
\text { institusi. }\end{array}$ \\
\hline $\begin{array}{l}\text { Level } 2 \\
\text { (Repeatable) }\end{array}$ & $\begin{array}{l}\text { a. Aktifitas TI dilakukan secara berulang, berjalan sebagai } \\
\text { kebiasaan/budaya tanpa adanya prosedur yang tertulis secara } \\
\text { jelas. } \\
\text { b. Indicator kinerja sedang dalam pengembangan . } \\
\text { c. Tidak ada pembagian tugas yang jelas dan tidak tertulis secara } \\
\text { jelas sehingga seorang petugas dapat menangani banyak aktifitas } \\
\text { TI. }\end{array}$ \\
\hline $\begin{array}{l}\text { Level } 3 \\
\text { (Defined) }\end{array}$ & $\begin{array}{l}\text { a. Pentingnya menerapkan tata kelola TI yang baik telah dipahami } \\
\text { dan diterima. } \\
\text { b. Aktifitas TI dilaksanakan mengacu pada procedure yang baku, } \\
\text { tertulis secara jelas dan didokumentasikan. } \\
\text { c. Pihak manajemen telah mengkomunikasikan standarisasi } \\
\text { procedure yang telah dibakukan. } \\
\text { d. Pembagian tugas dilakukan dengan jelas ,tertulis dan }\end{array}$ \\
\hline
\end{tabular}




\begin{tabular}{|c|c|}
\hline & didokumentasikan. \\
\hline $\begin{array}{l}\text { Level } 4 \\
\text { (Managed and } \\
\text { Measurable) }\end{array}$ & $\begin{array}{l}\text { a. Konsep tata kelola TI yang baik telah diterapkan secara } \\
\text { keseluruhan pada setiap lapisan yang terlibat (pengelola dan } \\
\text { pemakai ) dan disertai latihan formal. } \\
\text { b. Dikelola dengan baik, ukuran kinerja aktifitas TI dapat dinyatakan } \\
\text { dalam bentuk kwalitatif dan dapat dimonitor serta dianalisa } \\
\text { tingkat kepatuhannya terhadap prosedur yang telah ditetapkan } \\
\text { c. Didefenisikan toleransi terhadap efisiensi dan efektifitas hasil } \\
\text { pelaksanaan aktifitas. } \\
\text { d. Pembagian tugas/Tanggung-Jawab didefenisikan secara jelas } \\
\text { (pemilik/pelaksana aktifitas ditetapkan), tertulis, terdokumentasi } \\
\text { dan dimonitor. } \\
\text { Semua stakeholders yang terlibat (pengelola dan user ) menyadari } \\
\text { resiko, arti penting penerapan tata kelola TI dengan baik dan } \\
\text { benar. }\end{array}$ \\
\hline $\begin{array}{l}\text { Level } 5 \\
\text { (Optimised) }\end{array}$ & $\begin{array}{l}\text { a. Pelaksanaan aktifitas telah mengacu pada proses pembelajaran } \\
\text { terhadap pengalaman institusi ybs dan institusi lain. } \\
\text { b. TI digunakan secara luas (ekstensif), terintegrasi dan dilakukan } \\
\text { secara optimal untuk mengotomatisasi Workflow dan tersedia } \\
\text { tools untuk meningkatkan mutu dan efektivitas. } \\
\text { c. Resiko dan hasil pelaksanaan dari proses IT didefenisikankan, } \\
\text { dikomunikasikan dan disesuaikan antar Institusi. } \\
\text { d. Penggunaan teknologi yang optimal untuk mendukung } \\
\text { monitoring, pengukuran, analisa, pelatihan dan komunikasi. }\end{array}$ \\
\hline$l$ diisi, ma & $\begin{array}{l}\text { manajemen mengenai hasil yang didapatkan } \\
\text { agar supaya penilaian sistem informasi yang } \\
\text { dilakukan merupakan kondisi riil dari } \\
\text { pengelolaan yang sedang berjalan di } \\
\text { perusahaan. }\end{array}$ \\
\hline
\end{tabular}
yang dilakukan, serta kemudian dilakukan diskusi dan cross-check dengan pihak

Tabel 2.6 Representasi Tingkat Kematanga COBIT

Sumber : ITGI 2007)

\begin{tabular}{|c|cl|}
\hline $\mathbf{0 - 0 . 5}$ & $0:$ & Non Existent (Tidak ada) \\
\hline $\mathbf{0 . 5 1}-\mathbf{1 . 5}$ & $1:$ & Initial / Ad Hoc (Inisial) \\
\hline $\mathbf{2 . 5 1}-\mathbf{3 . 5}$ & $2:$ & Repeatable But Intuitive (Pengulangan proses berdasarkan intuisi) \\
\hline $\mathbf{2 . 5 1}-\mathbf{3 . 5}$ & $3:$ & Defined Process (Proses telah didefinisikan) \\
\hline $\mathbf{3 . 5 1}-\mathbf{4 . 5}$ & $4:$ & Managed and Measurable (Dikelola dan terukur) \\
\hline $\mathbf{4 . 5 1 - 5}$ & $5:$ & Optimised (Optimalisasi) \\
\hline
\end{tabular}

Indeks Kematangan Atribut setiap modul domain dipoeroleh dari menjumlahkan jumlah responden yang menjawab untuk setiap skala sikap pada setiap module domain dikalikan dengan bobot skala kemudian dibagi dengan jumlah responden seperti berikut ini :

Penghitungan Indeks Kematangan Atribut

Indeks Kematangan Atribut $=\frac{\sum(\text { Total Jawaban x Bobot })}{\text { Jumlah Responden }}$ 


\section{Indeks Kematangan $=\frac{\sum \text { Indeks Kematangan Atribut }}{\sum \text { Activities }}$}

(DR. Suhono Harsa Supangkat dan I Made Ari Jaya N., 2006)

Framework COBIT disusun dengan karakteristik berfokus pada bisnis (business focused), berorientasi pada proses (processoriented), berbasis pada pengendalian (controls-based) dan terarah kepada pengukuran (measurement-driven). Model kematangan (maturity models) adalah alat bantu yang dapat digunakan untuk melakukan benchmarking dan self-assement oleh manajemen TI untuk menilai kematangan proses TI.

Dengan model kematangan, manajemen bisa mengidentifikasi :

1. Kinerja aktual dari perusahaan - di mana posisi perusahaan saat ini.

2. Status industri sat ini - perbandingan
3. Target perbaikan bagi perusahaan - ke mana perushaaan ingin dibawa

4. Jalur pertumbuhan yang diperlukan antara " $a s-i s$ " dan " $t o-b e$ "

Secara umum, tingkat kematangan proses TI dibagi menjadi enam tingkat mulai dari tingkat kematangan 0 sampai dengan tingkat kematangan 5. Selain keenam tingkat tersebut, Tingkat Kedewasaan disusun oleh atribut-atribut sebagai berikut : 1. Awareness and Communication (AC)

2. Policies, Standards and Procedures (PSP)

3. Tools and Automation (TA)

4. Skills and Expertise (SE)

5. Responsibility and Accountabilyty (RA)

6. Goal Setting and Measurement (GSM)

Tabel 2.7 Tingkat Kedewaaan umum dalam COBIT 4.1

\begin{tabular}{|c|c|c|}
\hline \multicolumn{2}{|r|}{ Level } & Kriteria Kedewasaan \\
\hline 0 : & Non Existent & $\begin{array}{l}\text { Perusahaan bahkan tidak mengetahui bahwa terdapat permasalahan } \\
\text { yang harus diatasi }\end{array}$ \\
\hline 1: & $\begin{array}{l}\text { Initial / Ad } \\
\text { Hoc }\end{array}$ & $\begin{array}{l}\text { Tidak terdapat proses standar, namun menggunakan pendekatan ad hoc } \\
\text { yang cenderung diperlukan secara individu atau per kasus. }\end{array}$ \\
\hline 2: & $\begin{array}{l}\text { Repeatable } \\
\text { But Intuitive }\end{array}$ & $\begin{array}{l}\text { Proses dikembangkan ke dalam tahapan di mana proses yang serupa } \\
\text { diikuti oleh pihak-pihak yang berbeda untuk pekerjaan yang sama }\end{array}$ \\
\hline 3 : & $\begin{array}{l}\text { Defined } \\
\text { Process }\end{array}$ & $\begin{array}{l}\text { Prosedur distandarisasi dan didokumentasikan kemudian } \\
\text { dikomunikasian melalui pelatihan. }\end{array}$ \\
\hline 4: & $\begin{array}{l}\text { Managed and } \\
\text { Measurable }\end{array}$ & $\begin{array}{l}\text { Manajemen mengawasi dan mengukur kepatutan terhadap prosedur dan } \\
\text { mengambil tindakan jika proses tidak dapat dikerjakan secara efektif. }\end{array}$ \\
\hline & Optimised & $\begin{array}{l}\text { Proses telah dipilih ke dalam tingkat praktek yang baik berdasarkan } \\
\text { hasil dari perbaikan berkelanjutan dan permodelan kedewasaan dengan } \\
\text { perusahaan lain. }\end{array}$ \\
\hline
\end{tabular}

yang mana harus diperbaiki. Proses analisis gap mencakupo penetapan, dokumentasi, dan sisi positif keragaman keinginan dan kapabilitas (sekarang). Analisis gap untuk sistem informasi dalam pengelolaan pelayanan di Sub Bagian Perlengkapan dan Perbekalan BKKBN Perwakilan Provinsi ABCD dengan melihat dari kenyataan yang ada sekarang dan dengan harapan ke depannya memunculkan gap-gap sebagai berikut :

1. Perbedaan antara spesifikasi kualitas pelayanan pada Sub Bagian Perlengkapan dan Perbekalan BKKBN

alat membantu suatu (jarak) adalah suatu metode membandingkan performansi aktual dnegan performansi potensi. Operasionalnya dapat diungkapkan dengan dua pertanyaan berikut : "di mana kita sekarang?" dan "di mana kita inginkan?". Tujuan analisis gap untuk mengidentifikasi gap antara alokasi optimis dan integrasi input, serta ketercapaian sekarang. Analisis gap membantu organisasi/lembaga dalam mengungkapkan 
Perwakilan Provinsi ABCD dengan penyampaian pelayanan yang nyata. Gap ini dapat diatasi dengan standarisasi cara pelayanan kepada user. Dapat dilihat sekaran kualitas pelayanan di Sub Bagian Perlengkapan dan Perbekalan BKKBN Perwakilan Provinsi ABCD yang masih dapat ditingkatkan lagi, sedangkan harapannya adalah pihak Sub Bagian Perlengkapan dan Perbekalan BKKBN Perwakilan Provinsi ABCD sendiri dapat menambah atau meningkatkan layanan agar dirasakan oleh seluruh user yang terkait.

2. Perbedaan antara kualitas pelayanan yang diharapkan dengan yang dirasakan pemakai layanan.

3. Adanya kesenjangan antara layanan yang diinginkan oleh pengguna dengan layanan yang diberikan oleh Sub Bagian Perlengkapan dan Perbekalan BKKBN Perwakilan Provinsi ABCD. Dengan adanya perbedaan performance actual dan performance potensi ini dapat digunakan oleh Sub Bagian Perlengkapan dan Perbekalan BKKBN Perwakilan Provinsi ABCD sebagai bahan pertimbangan untuk evaluasi kebijakan manajemen. Apa yang bisa dilakukan perusahaan? Apa yang harus dilakukan perusahaan? Apa yang harus diketahui perusahaan? Apa yang perusahaan ketahui?

Selain itu, dalam kerangka kerja COBIT juga memaskkan bagian-bagian seperti :

1) Critical Success Factors (CSF)

Menetapkan masalah terpenting atau tindakan untuk manajemen mencapai pengendalian proses TI. CFS harus mengatur orientasi pedoman implementasi dan mengidentifikasi hal terpenting yang dilakukan secara strategis, teknis, organisasional atau prosedur.

2) Key Goal Indicators (KGI)

Menetapkan ukuran yang mengarahkan manajemen setelah fakta apakah proses IT telah mencapai kebutuhan bisnisnya, biasanya digambarkan atas kriteria informasi :

a) Ketersediaan informasi diperlukan untuk mendukung kebutuhan bisnis b) Ketiadaan atau kekurangan integritas dan resiko kerahasiaan

c) Efisiensi biaya dan operasi

d) Konfirmasi reliabilitas

e) Efektivitas dan Pemenuhan

3) Key Performance Indicators (KPI) Menetapkan ukuran untuk menentukan bagaimana proses TI dilaksanakan dengan baik yang memungkinkan tujuan tersebut tercapai. Secara ringkas dapat diuraikan sebagai berikut :

a) CSF, untuk mendapatkan proses dalam pengendalian

b) KGI, untuk memantau pencapaian tujuan proses

c) KPI, untuk memantau kinerja dalam setiap proses.

\section{METODOLOGI PENELITIAN}

Langkah-langkah pelaksanaan audit sistem informasi ini akan mengacu pada contoh yang baik (best practice) dengan kerangka kerja COBIT. Dalam pelaksanaanya, akan digunakan prosedur uji kepatutan di mana auditor akan mengevaluasi keadaan eksisting organisasi dengan standar pengelolaan proses TI yang didefinisikan dalam kerangka kerja COBIT.

\subsection{Perencanaan (Planning)}

Melakukan studi literatur terhadap dokumen Badan Kependudukan dan Keluarga Berencana Nasional (BKKBN) Provinsi ABCD yang berkaitan dengan Visi dan Misi, sasaran tujuan dan rencana strategis Badan Kependudukan dan Keluarga Berencana Nasional (BKKBN) Provinsi ABCD serta strategi, kebijakan-kebijakan yang terkait dengan pengelolaan investasi IT.

\subsubsection{Tujuan Audit}

Pada tahap ini peneliti harus menentukan bidang apa saja yang akan dilakukan audit. Audit sistem informasi pada Badan Kependudukan dan Keluarga Berencana Nasional (BKKBN) Provinsi ABCD ini dilakukan di Sub Bagian Perlengkapan dan 
Perbekalan dengan fokus pada proses pelayanan pengadaan barang, inventarisasi dan pemutakhiran data, dan perawatan. Dalam mengelola proses tersebut Sub Bagian Perlengkapan dan Perbekalan menggunakan beberapa aplikasi bantu. Pihak internal IT membangun aplikasi pendukung. Sampai saat ini pengimplementasian aplikasi tersebut belum pernah diaudit untuk memastikan keselarasan dengan tujuan bisnis TI.

\begin{tabular}{|c|l|l|}
\hline $\begin{array}{c}\text { Proses Pengendalian Sistem } \\
\text { Informasi }\end{array}$ & \multicolumn{2}{|c|}{$\begin{array}{c}\text { Faktor resiko yang harus dievaluasi, serta bagaimana } \\
\text { teknologi informasi dapat memenuhi manajemen informas }\end{array}$} \\
\hline \multirow{3}{*}{ DOMAIN } & DS1 & $\begin{array}{l}\text { Menetapkan dan mengatur tingkat layanan (define } \\
\text { and manage service levels) }\end{array}$ \\
\cline { 2 - 3 } & DS10 & $\begin{array}{l}\text { Mengelola kegiatan dan permasalahan (manage } \\
\text { problems and incidents) }\end{array}$ \\
\cline { 2 - 3 } & DS12 & Mengelola fasilitas (manage facilities) \\
\hline
\end{tabular}

\subsubsection{DS1 Menetapkan dan mengatur} tingkat layanan (define and manage service levels)

DS1. 1. Layanan tingkat manajemen

DS1. 2. Definisi Layanan

DS1. 3. Perjanjian Layanan

DS1. 4. Perjanjian Operasional

DS1. 5. Pemantauan dan pelaporan pencapaian layanan DS1.6. Review perjanjian dan kontrak

\subsubsection{DS10 Mengelola kegiatan dan permasalahan (manage problems and incidents)}

DS10. 1. Identifikasi dan klarisikasi masalah

DS10. 2. Pelacakan masalah dan solusi

DS10. 3. Penutupan / pengakhiran masalah

DS10. 4. Integrasi konfigurasi manajemen, kejadian dan masalah

\subsubsection{DS12 Mengelola fasilitas (manage facilities)}

\subsubsection{Ruang Lingkup Audit Sistem Informasi}

Ruang lingkup kerangka kerja COBIT berawal dari wawancara yang dilakukan peneliti kepada pihak yang terkait, dapat dilihat pada tabel 3.1
DS12. 1. Pemilihan lokasi dan tata letak

DS12.2. Tindakan keamanan fisik

DS12. 3. Akses fisik

DS12. 4. Perlindungan terhadap faktor lingkungan

DS12. 5. Fasilitas fisik manajemen

Berdasarkan pengelompokkan tersebut, dapat dijabarkan proses-proses TI yang terkait dengan domain yang telah ditentukan. Setelah diperoleh tujuan TI yang sesuai dengan perspektif proses pelayanan internal, maka selanjutnya adalah proses TI yang mendukung tujuan TI tersebut.

Pelaksanaan audit pada dasarnya melakukan pencarian bukti proses TI yanga da dalam institusi dengan menyesuaikan standar proses TI yang didefinisikan dalam COBIT. Bukti tersebut akan digunakan untuk melaksanakan perhitungan standar pelayanan sehingga dapat temuan yang dapat dijadikan sebagai bahan pertimbangan dalam penentuan tingkat pelayanan. Responden dalam penelitian ini dibagi menjadi 2 kategori, yaitu user dan manajemen.

\subsubsection{Studi Pustaka}


Studi pustaka dilakukan dengan mengumpulkan beberapa teori, metode atau model pada sub bagian perlengkapan dan perbekalan di bidang sistem informasi atapun teknologi informasi pada umumnya. Teori metode ataupun tersebut merupakan metode yang banyak digunakan dan menjadi acuan dalam kegiatan akademis, industri maupun praktisi teknologi informasi pada umumnya.

Adapun sasaran dari pustaka itu sendiri adalah :

1) Untuk dapat melihat gambaran umum mengenai metode dan kerangka kerja yang digunakan dalam ruang lingkup audit sistem informasi.

2) Membandingkan kerangka kerja yang ada, dengan melakukan identifikasi pola serta mencari kesepadanan dalam kerangka kerja tersebut yang dijadikan sebagai alat untuk mengkaji pengelolaan investasi teknologi informasi perusahaan.

\subsection{Pemeriksaan Lapangan (Field Work)}

Penelitian ini bersifat pendekatan survei. Alat analisis yang digunakan dalam penelitian ini adalah dengan prosedur standar COBIT (Control Objective for Information and Related Technology) yang dikeluarkan oleh ISACA (Information systems Audit and Control Association).

Data yang dipergunakan dalam penelitian ini adalah data primer dan sekunder yang diperoleh dengan metode kuisioner tentang pelayanan di Sub Bagian Perlengkapan dan
Perbekalan pada BKKBN Provinsi ABCD dan melalui data-data yang telah dipublikasi secara internal dan dapat dijaga keabsahannya. Description of maturity level terdiri dari enam level (0 sampai 5) yang menggambarkan tingkat kehandalan aktivitas pengendalian sistem informasi yang dirangkum oleh ISACA dari konsensus berbagai pendapat ahli dan praktek terbaik di bidang teknologi informasi yang bersifat generik dan telah dijadikan sebagai standar internasional. Adapun jumlah populasi sebanyak 407 orang dan berdasarkan rumus pada pengambilan sampel didapati responden berjumlah 69 orang, pengukuran dilakukan terhadap fakta-fakta kematangan pengendalian proses yang terjadi di dalam organisasi dengan mneggunakan kuesioner yang dirancang melalui COBIT Management Guidelines. Description of maturity level dapat digambarkan sebagai sekelompok pernyataan yang terstruktur di mana masingmasing deskripsi berisi pernyataan yang dapat bernilai sesuai atau tidak sesuai, dan sebagian sesua atau sebagian tidak sesua. Data yang diperoleh dapat dengan berbagai metode yaitu :

a. Kuisioner, yaitu dengan cara membagikan kuisioner kepada setiap bagian yang tergolong manajemen. Adapun jumlah manajemen yang tersebar sejumlah 19. Selain itu kuisioner yang disebarkan kepada user sejumlah 50 responden sehingga secara keseluruhan didapat total responden 69 orang dengan rincian dapat dilihat pada tabel 3.2 berikut.

\begin{tabular}{|c|c|c|}
\hline No & & Kategori Responden \\
\hline 1 & Manajemen & $\begin{array}{l}\text { 1. Kepala Perwakilan BKKBN Provinsi ABCD } \\
\text { 2. Sekretaris } \\
\text { 3. Auditor } \\
\text { 4. Kepala Bidang Informatika Keluarga dan Analisis Program } \\
\text { 5. Kepala Bidang Pengendalian KB dan Kes. Reproduksi } \\
\text { 6. Kepala Bidang Pengendalian K.S dan Pemberdayaan } \\
\text { Keluarga } \\
\text { 7. Kepala Bidang Pelatihan dan Pengembangan } \\
\text { 8. Ka. Subbag Perencanaan } \\
\text { 9. Ka. Subbag Hukum dan Kepegawaian } \\
\text { 10. Ka. Subbag Tata Usaha } \\
\text { 11. Ka. Subbag Perlengkapan dan Perbekalan } \\
\text { 12. Ka. Subbag Supervisi Program Ketenagaan } \\
\text { 13. Ka. Subbag Supervisi Umum } \\
\text { 14. Ka. Subbag Pengolahan Pelayanan Informasi dan Dokumen }\end{array}$ \\
\hline
\end{tabular}




\begin{tabular}{|c|c|c|}
\hline & & $\begin{array}{l}\text { 15. Ka. Subbag Analisis dan Evaluasi Program } \\
\text { 16. Ka. Subbag Pelaporan dan Statistika } \\
\text { 17. Ka. Subbag Remaja dan perlindungan Hak-Hak Reproduksi } \\
\text { 18. Ka. Subbag Advokasi, Komunikas, Informasi dan } \\
\text { Dokumentasi } \\
\text { 19. Ka. Subbag Jaminan Pelayanan KB }\end{array}$ \\
\hline 2 & User & $\begin{array}{l}\text { 1. Seksi Supervisi Program Ketenagaan } 4 \text { orang } \\
\text { 2. Seksi Supervisi Umum } 4 \text { orang } \\
\text { 3. Seksi Pengolahan Pelayanan Informasi dan Dokumen } 5 \\
\text { orang } \\
\text { 4. Seksi Analisis dan Evaluasi Program } 5 \text { orang } \\
\text { 5. Seksi Pelaporan dan Statistika } 4 \text { orang } \\
\text { 6. Seksi Remaja dan Perlindungan Hak-Hak Reproduksi } 5 \\
\text { orang } \\
\text { 7. Seksi Peningkatan Partispasi Pria } 3 \text { orang } \\
\text { 8. Seksi Penanggulangan Masalah PMKR dan KHIBA } 2 \text { orang } \\
\text { 9. Seksi Jaminan Pelayanan KB } 1 \text { orang } \\
\text { 10. Seksi Advokasi, Komunikasi, Informasi dan Dokumentasi } 1 \\
\text { orang } \\
\text { 11. Seksi Institusi dan Peran Serta } 1 \text { orang } \\
\text { 12. Seksi Pengembangan Keluarga dan Peningkatan Keluarga } \\
\text { Lingkungan Keluarga } 2 \text { orang } \\
\text { 13. Seksi Pemberdayaan Ekonomi Keluarga } 2 \text { orang } \\
\text { 14. Seksi Penyelenggaraan } 3 \text { orang } \\
\text { 15. Seksi Program dan Evaluasi } 3 \text { orang } \\
\text { 16. Widya Iswara } 5 \text { orang }\end{array}$ \\
\hline
\end{tabular}

b. Studi Pustaka, yaitu dengan cara mempelajari literatur yang relevan dengan penelitian guna memperoleh gambaran teoritis mengenai pengevaluasian keutuhan TI dengan metode maturity level pada kerangka kerja COBIT. Selain itu untuk menunjang kelengkapan dan ketajaman analisis, diperlukan sumber referensi seperti : teksbook, prosiding, internet dan makalah ilmiah yang relevan dengan penelitian ini.

c. Rencana kegiatan penelitian yang akan dilakukan adalah penyebaran kuisioner dan melakukan wawancara dengan pihak terkait untuk mendapatkan data yang akan diproses / dihitung menggunakan rumusan maturity level.

\subsection{Teknik Pengolahan Data}

Pengolahan data ini bertujuan untuk menentukan posisi maturity model berdasarkan pendekatan COBIT yang telah dicapai perusahaan pada saat ini. Dalam penelitian ini, digunakan penilaian yang dikemukakan oleh ITGI (2007) untuk dapat mengukur maturity model dengan langkahlangkah sbeagai berikut :

a. Rentang jawaban dibagi dalam 5 skala yaitu : 1-2-3-4-5 dengan pemenuhan (compliance value) terhadap masingmasing skala yaitu : $1-2-3-4-5$ masing-masing bobot dari pemenuhan tersebut menunjukkan tingkat persetujuan terhadap pertanyaan.

b. Setiap angka pada maturity level compliance value (C) kemudian dibagi dengan total keseluruhan perolehan maturity level compliance value, sehingga akan diperooleh normalized maturity level compliance value.

c. Setiap angka pada maturity level (M) kemudian dikalikan dengan normalized maturity level compliance value dari masing-masing level (D) sehingga nantinya akan diperoleh nilai kontribusi untuk setiap maturity level.

Selaras dengan metode COBIT, Skala Likert digunakan untuk mengukur sikap, pendapat dan persepsi seseorang atau sekelompok orang tentang fenomena sosial. Dengan Skala Likert, variabel akan diukur dijabarkan menjadi indikator variabel. Kemudian indikator tersebut dijadikan 
sebagai titik tolak untuk menyusun itemitem instrumen yang dapat berupa pertanyaan atau pernyataan. Jawaban setiap item instrumen yang menggunakan Skala Likert mempunyai gradasi dari sangat positif sampai sangat negatif, yang dapat berupa kata-kata antara lain : Sangat Penting (SP), Penting (P), Ragu-ragu (R), Tidak Penting (TP), Sangat Tidak Penting (STP).

Tabel 3.3 Representasi Tingkat Kematangan COBIT

\begin{tabular}{|c|l|}
\hline $\mathbf{0}-\mathbf{0 . 5}$ & $0:$ Non Existent (Tidak Ada) \\
\hline $\mathbf{0 . 5 1}-\mathbf{1 . 5}$ & 1 : Initial / Ad Hoc (Inisial) \\
\hline $\mathbf{1 . 5}-\mathbf{2 . 5}$ & 2: Repeatable But Intuitive (Pengulangan Proses berdasarkan Intuisi) \\
\hline $\mathbf{2 . 5 1}-\mathbf{3 . 5}$ & 3: Defined Process (Proses telah didefinisikan) \\
\hline $\mathbf{3 . 5 1}-\mathbf{4 . 5}$ & 4: Managed and Measurable (Dikelola dan Terukur) \\
\hline $\mathbf{4 . 5 1}-\mathbf{5}$ & 5: Optimised (Optimalisasi) \\
\hline
\end{tabular}

Sumber : ITGI (2007)

\subsection{Pelaporan (Reporting)}

Setelah kuisioner disebarkan, maka akan didapat data yang akan diproses untuk dihitung berdasarkan perhitungan maturity level. Untuk selanjutnya dilakukan beberapa tahapan dalam pelaporan, yaitu :

- Hasil audit berisi temuan sekarang (current maturity level) dan harapan pada masa yang akan datang (expected maturity level)

- Dilakukan analisis gap untuk melakukan analisa interprestasi hasil current maturity level dan expected.

- Rekomendasi berisi tindakan korektif mengatasi gap yang dilakukan untuk mendapai perbaikan yang dilakukan untuk institusi tersebut. Tindakan ini bagaimana menghasilkan nilai sistem infomrasi yang optimal.

\subsection{Tindak Lanjut (Follow Up)}

Setelah rekomendasi diserahkan kepada BKKBN Provinsi ABCD, maka untuk selanjutnya wewenang perbaikan menjadi tanggung jawab pihak BKKBN Provinsi ABCD apakah akan diterapkan atau hanya menjadi acuan untuk perbaikan di masa yang akan datang.

\section{HASIL DAN PEMBAHASAN}

Pada bab ini membahas hasil analisa yang diperoleh dari penyebaran kuesioner, selama pelaksanaan audit sistem informasi manajemen asset yang baru nilai kematangan tiap-tiap proses, serta temuan hingga membuat rekomendasi untuk meningkatkan kematangan keberlangsungan proses bisnis di kemudian hari.

\subsection{Hasil Evaluasi Maturity Level saat ini (Performance)}

Sistem Informasi pada Sub Bagian Perlengkapan dan Perbekalan BKKBN Provinsi ABCD yang ada pada saat ini berdasarkan pengamatan peneliti, masih terdapat kekurangan pada menertibkan perjanjian dengan user yang terkait dan operasional, bagaimana melakukan pemantauan dan pelaporan pencapaian layanan, review perjanjian kontrak, menyelesaikan masalah yang ada dan mengantisipasi agar tidak terjadi permasalahan yang sama, dan terakhir adalah bagaimana melakukan tindakan keamanan terhadap aset secara fisik serta bagaimana pengaturan tata letak agar aset dapat dimaksimalkan kegunaannya.

Secara umum sistem informasi TI saat ini dapat dilihat dari hasil perhitungan kematangan (maturity level) sistem informasi pada Sub Bagian Perlengkapan dan Perbekalan BKKBN Provinsi ABCD pada level manajemen yang selengkapnya dapat dilihat pada tabel 4.1 dan tabel 4.2. 
Tabel 4.1 Tabel Tingkat Kematangan Maturity Level Sub Bagian Perlengkapan dan Perbekalan responden kategori manajemen

\begin{tabular}{|l|l|c|c|}
\hline \multicolumn{1}{|c|}{ Domain } & \multicolumn{1}{|c|}{ Proses } & $\begin{array}{c}\text { Current } \\
\text { Maturity }\end{array}$ & $\begin{array}{c}\text { Expected } \\
\text { Maturity }\end{array}$ \\
\hline DS1.1 & Layanan Tingkat Manajemen & 3.40 & 4.36 \\
\hline DS1.2 & Definisi Layanan & 3.34 & 4.26 \\
\hline DS1.3 & Perjanjian Layanan & 3.17 & 4.44 \\
\hline DS1.4 & Perjanjian Operasional & 3.36 & 4.28 \\
\hline DS1.5 & Pemantauan dan Pelaporan Pencapaian Layanan & 3.38 & 4.27 \\
\hline DS1.6 & Review Perjanjian dan Kontrak & 3.36 & 4.26 \\
\hline DS10.1 & Identifikasi dan Klasifikasi Masalah & 3.42 & 4.25 \\
\hline DS10.2 & Pelacakan Masalah dan Solusi & 3.44 & 4.25 \\
\hline DS10.3 & Penutupan / Pengakhiran Masalah & 3.50 & 4.38 \\
\hline DS10.4 & Integrasi Konfigurasi Manajemen, Kejadian dan & 3.40 & 4.22 \\
\hline DS12.1 & Masalah & & \\
\hline DS12.2 & Tindakan Keamanan Fisik & 3.41 & 4.29 \\
\hline DS12.3 & Akses Fisik & 3.50 & 4.38 \\
\hline DS12.4 & Perlindungan terhadap faktor lingkungan & 3.44 & 4.29 \\
\hline DS12.5 & Fasilitas Fisik Manajemen & 3.54 & 4.35 \\
\hline
\end{tabular}

Tabel 4.2 Tabel Tingkat Kematangan Maturity Level Sub Bagian Perlengkapan dan Perbekalan responden kategori user

\begin{tabular}{|l|l|c|c|}
\hline \multicolumn{1}{|c|}{ Domain } & \multicolumn{1}{|c|}{ Proses } & $\begin{array}{c}\text { Current } \\
\text { Maturity }\end{array}$ & $\begin{array}{c}\text { Expected } \\
\text { Maturity }\end{array}$ \\
\hline DS1.1 & Layanan Tingkat Manajemen & 3.39 & 3.92 \\
\hline DS1.2 & Definisi Layanan & 3.47 & 4.69 \\
\hline DS1.3 & Perjanjian Layanan & 3.76 & 4.31 \\
\hline DS1.4 & Perjanjian Operasional & 3.46 & 4.21 \\
\hline DS1.5 & Pemantauan dan Pelaporan Pencapaian Layanan & 3.48 & 3.90 \\
\hline DS1.6 & Review Perjanjian dan Kontrak & 3.44 & 3.94 \\
\hline DS10.1 & Identifikasi dan Klasifikasi Masalah & 3.50 & 4.00 \\
\hline DS10.2 & Pelacakan Masalah dan Solusi & 3.57 & 4.09 \\
\hline DS10.3 & Penutupan / Pengakhiran Masalah & 3.48 & 4.04 \\
\hline DS10.4 & Integrasi Konfigurasi Manajemen, Kejadian dan & 3.31 & 4.40 \\
\hline DS12.1 & Masalah & & \\
\hline DS12.2 & Tindakan Keamanan Fisik & 3.50 & 4.15 \\
\hline DS12.3 & Akses Fisik & 3.66 & 4.01 \\
\hline DS12.4 & Perlindungan terhadap faktor lingkungan & 3.37 & 4.15 \\
\hline DS12.5 & Fasilitas Fisik Manajemen & 3.72 & 4.38 \\
\hline
\end{tabular}

Maturity Level pada tabel 4.1 diperoleh dari hasil rata-rata kuesioner yang disebar kepada 69 responden yang dibagi menjadi 2 kategori, user dan manajemen secara rinci dapat dilihat pada lampiran 1 (satu).
Current Maturity Level saat ini (performance) pada Sub Bagian Perlengkapan dan Perbekelan responden kategori user dan manajemen dapat juga digambarkan 4.1 dalam grafik radar berikut : 


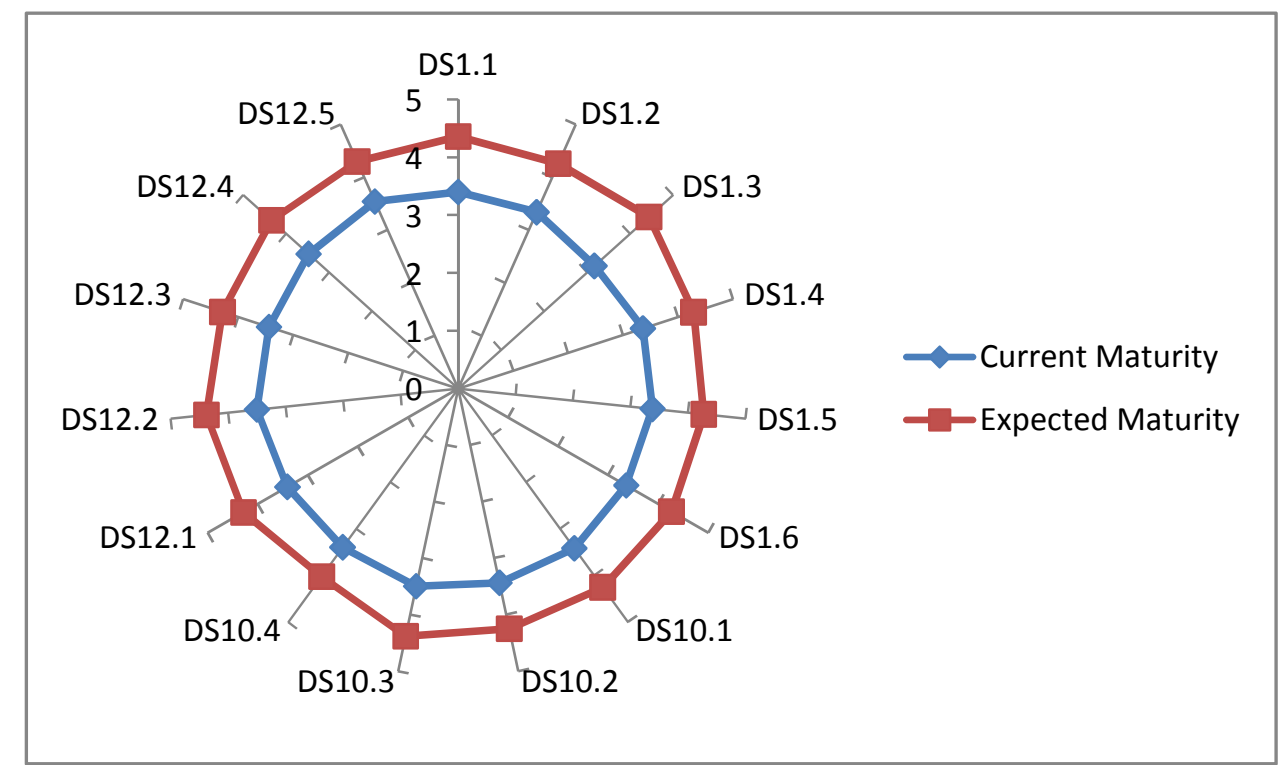

Gambar 4.1 Performance User dan Manajemen

Secara umum maturity level Sub Bagian Perlengkapan dan Perbekalan dengan menjumlah dan merata-ratakan dari rata-rata setiap kategori maka didapat tingkat kematangan (maturity level) sistem inforasi Sub Bagian Perlengkapan dan perbekalan pada BKKBN Provinsi ABCD yang selengkapnya dapat dilihat pada tabel 4.3.

Tabel 4.3 Nilai Maturity Sub Bagian Perlengkapan dan Perbekelan pada BKKBN Provinsi ABCD menurut responden kategori user dan kategori manajemen saat ini (performance).

\begin{tabular}{|l|l|c|}
\hline \multicolumn{1}{|c|}{ Domain } & \multicolumn{1}{|c|}{ Proses } & \multicolumn{1}{c|}{ Current Maturity } \\
\hline Delivery and Support & Manajemen & 3.50 \\
\hline Delivery and Support & User & 3.40 \\
\hline Nilai Maturity menurut Manajemen dan User & $\mathbf{3 . 4 5}$ \\
\hline \\
Dari gambar dan tabel 4.3 dapat dilihat & $\begin{array}{l}\text { pendekatan } \\
\text { sudah terorganisasi. }\end{array}$
\end{tabular}

bahwa rata-rata tingkat kematangan saat ini (current maturity level) untuk domain Deliver and Support berada di sekitar level 3 (Defined). Hal ini dapat dikatakan bahwa dalam proses sistem informasi Sub Bagian Perlengkapan dan Perbekalan BKKBN Provinsi ABCD terdapat beberapa permasalahan yang harus diketahui oleh perusahaan, adanya permasalahan yang harus diatasi dalam waktu yang cepat, bagaimanapun juga tidak terdapat proses standar, namun menggunakan pendekatan defined yang cenderung diperlakukan secara individu atau per kasus. Secaraumum

\subsection{Analisa Kesenjangan Manajemen}

Acuan dalam sistem informasi Sub Bagian Perlengkapan dan Perbekalan BKKBN Provinsi ABCD yang diberikan oleh pelayanan dengan menggunakan kerangka kerja COBIT 4.1 adalah maturity level. Dari gambar 4.1 dan hasil kuesioner yang disebarkan terdapat expected maturity level di level managed and measurable adalah pada level 4. Ternyata hasil perhitungan current maturity level untuk proses Sub Bagian Perlengkapan dan Perbekalan yang berjalan saat ini berada dibawah expected 
maturity level. Berikut ini gap tingkat kematangan sistem informasi Sub Bagian Perlengkapan dan Perbekalan BKKBN
Provinsi ABCD yang digabamrkan dalam tabel 4.4 berikut:

Tabel 4.4 Gap tingkat kematangan sistem informasi Sub Bagian Perlengkapan dan Perbekalan

\begin{tabular}{|l|l|c|c|}
\hline \multicolumn{1}{|c|}{ Domain } & \multicolumn{1}{|c|}{ Proses } & $\begin{array}{c}\text { Current } \\
\text { Maturity }\end{array}$ & $\begin{array}{c}\text { Expected } \\
\text { Maturity }\end{array}$ \\
\hline DS1 & Defined and manage services levels & 3.33 & 4.31 \\
\hline DS 10 & Manage problems and incidents & 3.44 & 4.22 \\
\hline DS12 & Manage Facilities & 3.47 & 4.32 \\
\hline
\end{tabular}

Tingkat kematangan saat ini (current maturity level) yang terendah dalam domain DS berada pada proses DS1 yaitu menetapkan dan mengatur tingkat layanan kepada user yang berada pada level 3.33, disebabkan pada proses DS1.3 yaitu perjanjian layanan, sementara itu tingkat kematangan saat ini (current maturity level) yang tertinggi dalam domain DS berada pada proses DS12 yaitu mengelola fasilitas yang berada pada level 3.47.

Untuk lebih jelasnya data perolehan dari respoden dan pengolahannya dapat dilihat pada lampiran rekap hasil kuesioner.

\subsection{Hasil Evaluasi Maturity Level yang diharapkan (Expectacy)}

Sistem informasi pada Sub Bagian Perlengkapan dan Perbekalan di masa yang akan datang diharapkan dapat memenuhi proses yang dirasakan kurang pada performance yaitu : sudah tertibnya perjanjian dengan user, konsisten melakukan pemantauan dan pelaporan pencapaian layanan, review perjanjian kontrak, menyelesaikan masalah yang ada dan sudah memiliki standar penyelesaian pada masalah yang terjadi, dan terakhir adalah menjelaskan prosedur tingkat keamanan terhadap asset secara fisik serta pengaturan tata letak asset yang sesuai dengan standar yang ada.

Secara umum sistem informasi TI saat ini dapat dilihat dari hasil perhitungan tingkat kematangan (maturity level) sistem informasi Sub Bagian Perlengkapan dan perbekalan di BKKBN Provinsi ABCD pada level manajemen yang selengkapnya dapat dilihat pada tabel 4.5 dan tabel 4.6.

Tabel 4.5 Expected Maturity Level Sub Bagian Perlengkapan dan Perbekalan responden kategori manajemen

\begin{tabular}{|l|l|c|}
\hline \multicolumn{1}{|c|}{ Domain } & \multicolumn{1}{|c|}{ Proses } & $\begin{array}{c}\text { Expected } \\
\text { Maturity }\end{array}$ \\
\hline DS1.1 & Layanan Tingkat Manajemen & 4.36 \\
\hline DS1.2 & Definisi Layanan & 4.26 \\
\hline DS1.3 & Perjanjian Layanan & 4.44 \\
\hline DS1.4 & Perjanjian Operasional & 4.28 \\
\hline DS1.5 & Pemantauan dan Pelaporan Pencapaian Layanan & 4.27 \\
\hline DS1.6 & Review Perjanjian dan Kontrak & 4.26 \\
\hline DS10.1 & Identifikasi dan Klasifikasi Masalah & 4.25 \\
\hline DS10.2 & Pelacakan Masalah dan Solusi & 4.25 \\
\hline DS10.3 & Penutupan / Pengakhiran Masalah & 4.38 \\
\hline DS10.4 & Integrasi Konfigurasi Manajemen, Kejadian dan Masalah & 4.22 \\
\hline DS12.1 & Pemilihan Lokasi dan Tata Letak & 4.29 \\
\hline DS12.2 & Tindakan Keamanan Fisik & 4.38 \\
\hline DS12.3 & Akses Fisik & 4.29 \\
\hline DS12.4 & Perlindungan terhadap faktor lingkungan & 4.35 \\
\hline DS12.5 & Fasilitas Fisik Manajemen & 4.60 \\
\hline
\end{tabular}


Tabel 4.6 Expected Maturity Level Sub Bagian Perlengkapan dan Perbekalan responden kategori user

\begin{tabular}{|l|l|c|}
\hline \multicolumn{1}{|c|}{ Domain } & \multicolumn{1}{|c|}{ Proses } & $\begin{array}{c}\text { Expected } \\
\text { Maturity }\end{array}$ \\
\hline DS1.1 & Layanan Tingkat Manajemen & 3.92 \\
\hline DS1.2 & Definisi Layanan & 4.69 \\
\hline DS1.3 & Perjanjian Layanan & 4.31 \\
\hline DS1.4 & Perjanjian Operasional & 4.21 \\
\hline DS1.5 & Pemantauan dan Pelaporan Pencapaian Layanan & 3.90 \\
\hline DS1.6 & Review Perjanjian dan Kontrak & 3.94 \\
\hline DS10.1 & Identifikasi dan Klasifikasi Masalah & 4.00 \\
\hline DS10.2 & Pelacakan Masalah dan Solusi & 4.09 \\
\hline DS10.3 & Penutupan / Pengakhiran Masalah & 4.04 \\
\hline DS10.4 & Integrasi Konfigurasi Manajemen, Kejadian dan Masalah & 4.40 \\
\hline DS12.1 & Pemilihan Lokasi dan Tata Letak & 4.15 \\
\hline DS12.2 & Tindakan Keamanan Fisik & 4.01 \\
\hline DS12.3 & Akses Fisik & 4.15 \\
\hline DS12.4 & Perlindungan terhadap faktor lingkungan & 4.38 \\
\hline DS12.5 & Fasilitas Fisik Manajemen & 4.32 \\
\hline
\end{tabular}

Expected Maturity level pada Sub Bagian

digambarkan 4.2 dalam grafirk radat berikut Perlengkapan dan Perbekalan responden kategori user dan manajemen dapat juga

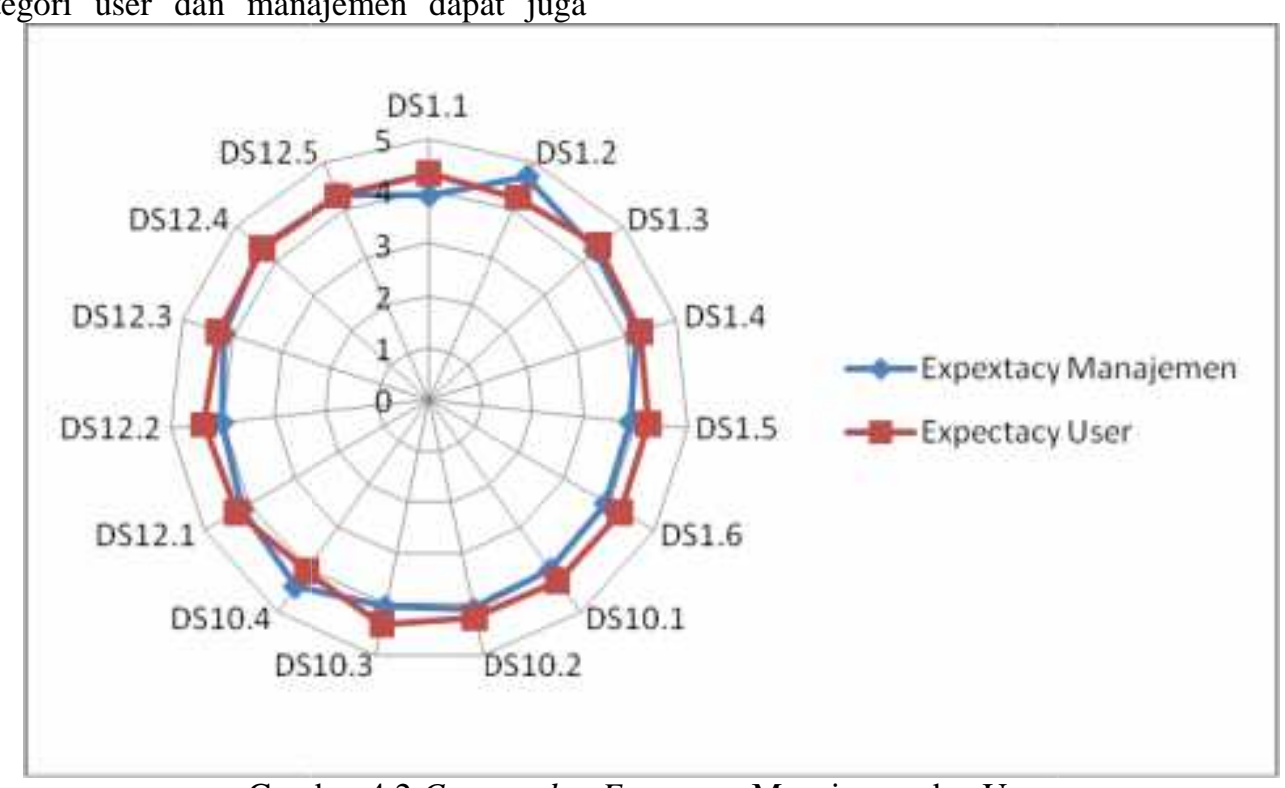

Gambar 4.2 Current dan Expectacy Manajemen dan User

Secara umum maturity level Sub Bagian perlengkapan dan perbekalan dengan menjumlah dan merata-ratakan dari rata-rata setiap kategori, maka didapat tingkat kematangan (maturity level) sistem informasi Sub Bagian Perlengkapan pada BKKBN Provinsi ABCD yang selengkapnya dapat dilihat pada tabel 4.7 .

Tabel 4.7 Nilai Maturity Sub Bagian Perlengkapan dan Perbekelan pada BKKBN Provinsi ABCD menurut responden kategori user dan kategori manajemen saat ini (performance).

\begin{tabular}{|l|l|c|}
\hline \multicolumn{1}{|c|}{ Domain } & \multicolumn{1}{|c|}{ Proses } & Expected Maturity \\
\hline Delivery and Support & Manajemen & 4.16 \\
\hline Delivery and Support & User & 4.32 \\
\hline Nilai Maturity menurut Manajemen dan User & $\mathbf{4 . 2 4}$ \\
\hline
\end{tabular}


Dari gambar 4.2 dan tabel 4.7 dapat dilihat bahwa rata-rata tingkat kematangan saat ini (current maturity level) untuk domain Deliver and Support berada di sekitar level 4 (Managed and Measurable). Hal ini dapat dikatakan bahwa dalam proses sistem informasi Sub Bagian Perlengkapan dan Perbekalan BKKBN Provinsi ABCD tidak terdapat permasalahan, permasalahan yang ada dapat diatasi dalam waktu cepat. Harus terdapat proses standar, telah menggunakan pendekatan managed and measurable yang cenderung diperlakukan sesuai dengan standar yang ada. Secara umum pendekatan kepada pengelolaan proses sudah terorganisasi dengan baik.

\subsection{Analisa Kesenjangan User}

Acuan dalam sistem informasi Sub Bagian Perlengkapan dan Perbekalan BKKBN Provinsi ABCD yang diberikan oleh pelayanan dengan menggunakan kerangka kerja COBIT 4.1 adalah maturity level. Dari hasil kuesioner yang disebarkan terdapat expected maturity level di level managed and measurable adalah pada level 4. Hasil perhitungan current maturity level untuk proses Sub Bagian Perlengkapan dan Perbekalan yang berjalan saat ini berada di bawah expected maturity level.

Tabel 4.8 Gap tingkat kematangan maturity level domain Deliver and Support

\begin{tabular}{|l|l|c|c|}
\hline \multicolumn{1}{|c|}{ Domain } & \multicolumn{1}{|c|}{ Proses } & $\begin{array}{c}\text { Current } \\
\text { Maturity }\end{array}$ & $\begin{array}{c}\text { Expected } \\
\text { Maturity }\end{array}$ \\
\hline DS1 & Defined and manage services levels & 3.46 & 4.16 \\
\hline DS 10 & Manage problems and incidents & 3.50 & 4.13 \\
\hline DS12 & Manage Facilities & 3.54 & 4.20 \\
\hline
\end{tabular}

Tingkat kematangan saat ini (current maturity level) yang terendah dalam domain DS berada pada proses DS1 yaitu menetapkan dan mengatur tingkat layanan kepada user yang berada pada level 3.46, disebabkan pada proses DS1.3 yaitu perjanjian layanan, sementara itu tingkat kematangan saat ini (current maturity level) yang tertinggi dalam domain DS berada pada proses DS12 yaitu mengelola fasilitas yang berada pada level 3.54.
Untuk lebih jelasnya data perolehan dari respoden dan pengolahannya dapat dilihat pada lampiran rekap hasil kuesioner.

Sementara itu tingkat kematangan saat ini (current maturity level) dan tingkat kematangan yang diharapkan expected maturity level dapat digambarkan pada gambar 4.3. 


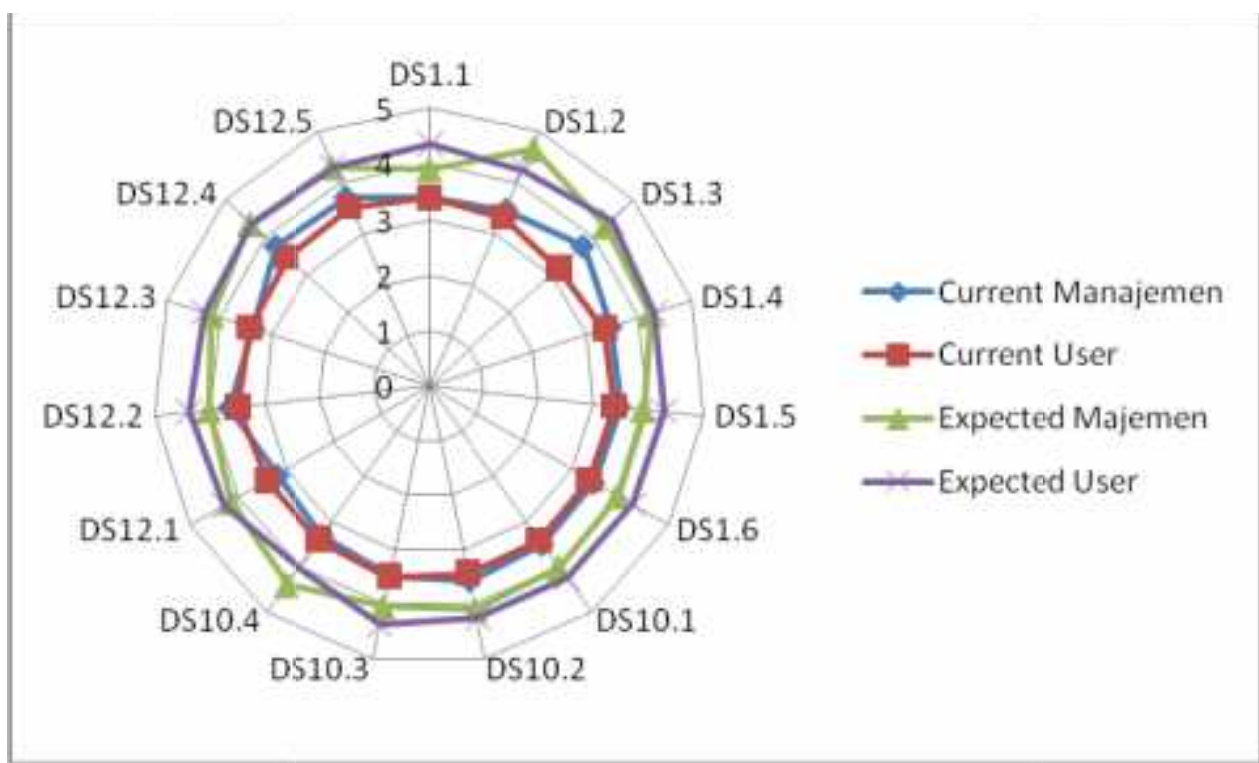

Gambar 4.3 Analisa Kesenjangan User

\subsection{Analisa Gap Maturity Level proses- proses TI dalam Pelaksanaan Sistem Informasi pada Sub Bagian Perlengkapan dan Perbekalan}

Berdasarkan dari tabel 4.8 dan gambar 4.3 hasil perhitungan current maturity level dan expected yang dihasilkan dengan menggunakan kerangka kerja COBIT 4.1, sebagai acuan untuk mengukur maturity level dalam sistem informasi TI, di mana tingkat kematangan atau maturity level yang diharapkan (expected maturity level) adalah pada level 3 (defined process), perhitungan maturity level untuk proses TI yang ada pada saat ini current maturity level masih di bawah maturity level yang diharapkan (expected maturity level). Untuk itu harus diakukan analisis menutupi gap antara current maturity level dan expected maturity level tersebut. Tabel 4.8 memperlihatkan gap antara maturity level untuk setiap proses COBIT dalam domain DS01, DS10, dan DS12 pada Sistem Informasi Sub Bagian Perlengkapan dan Perbekalan.

\subsection{Implikasi Manajemen}

\subsubsection{Implikasi Manajemen pada DS1}

Berdasarkan hasil evaluasi responden kategori manajemen maupun kategori user, model kematangan Sub Bagian Perlengkapan dan Perbekalan pada Domain
DS1 menggunakan Framework COBIT, berada pada Level 3 (Defined Process), dengan kriteria kedewasaan: "Telah terdapat kesadaran akan pelayanan dan telah dipromosikan oleh manajemen".

Prosedur pelayanan IT telah didefinisikan dan selaras dengan kebijakan IT. Tanggungjawab untuk pelayanan TI telah diberikan dan dipahami, namun tidak konsisten ditegakkan. Sebuah rencana pelayanan TI dan solusi pelayanan telah tersedia, didorong oleh analisis resiko. Pelaporan mengenai pelayanan tidak mengandung fokus bisnis yang jelas. Pengujian pelayanan Ad Hoc (misalnya, pengujian instruksi) telah dilakukan. Pelatihan pelaanan untuk TI dan bisnis telah tersedia, tetapi hanya dijadwalkan dan dkelola secara informal.

\subsubsection{Implikasi Manajemen pada DS10}

Berdasarkan hasil evaluasi responden kategori manajemen maupun kategori user, model kematangan IT Sub Bagian Perlengkapan dan Perbekalan pada Domain DS10 menggunakan framework Cobit, berada pada level 3 (defined process) dengan kriteria kedewasaan: "personil mengenali kebutuhan untuk mengelola dan menyelesaikan penyebab masalah. Personil kunci berpengetahuan memberikan beberapa bantuan terhadap masalah yang berkaitan 
dengan bidang keahlian mereka, tangung jawab atas manajemen masalah telah ditugaskan. Informasi telah disebarkan, sehingga mengurangi masalah yang akan datang, tetapi metode dalam pengelolaan kegiatan dan penyelesaian masalah perlu ditingkatkan lagi agar lebih dirasakan oleh seluruh penerima layanan Sub Bagian Perlengkapan dan Perbekalan pada BKKBN Provinsi ABCD".

\subsubsection{Implikasi Manajemen pada DS12}

Berdasrakan hasil evaluasi responden kategori manajemen maupun kategori user, model kematangan IT pada Domain DS12 menggunakan framework Cobit, berada pada level 3 (defined process) dengan kriteria kedewasaan : "menyediakan lingkungan fisik yang sesuai yang melindungi sumber daya dan personil terhadap bahaya buatan manusia dan alam. Manajemen sarana dan peralatan telah dikelola dan terukur secara baik. Personil dapat bergerak di dalam fasilitas yang sangat mendukung dalam mengelola fasilitas yang telah disediakan oleh BKKBN Provinsi ABCD. Manajemen selalu memonitor pengendalian fasilitas lingkungan atau pergerakan personil."

Usulan pengelolaan proses pada Sub Bagian Perlengkapan dan Perbekalan, berdasarkan hasil analisa kebutuhan dihasilkan model tata kelola IT pada masing-masing proses model tersebut meliputi :

\subsubsection{Critical Success Factor (CSF), Key Performance Indicator (KPI) pada Delivery and Support (DS)}

Usulan pengelolaan proses pada Sub Bagian Perlengkapan dan Perbekalan berdasrakan hasil analisa kebutuhan yang dihasilkan model tatakelola IT pada masing-masng proses. Model tersebut meliputi :

\subsubsection{Critical Success Factor (CSF) pada DS01}

Menetapkan dan mengatur tingkat layanan untuk Sub Bagian Perlengkapan dan Perbekalan pada BKKBN Provinsi ABCD untuk mencapai pengendalian proses TI. Merupakan kondisi-kondisi, kompetensi dan perilaku yang bersifat kritis terhadap keberhasilan pencapaian tujuan, yaitu :

a. Pelayanan dan pengolahan perjanjian layanan dan operasional TI harus ditingkatkan, dengan meningkatnya pelayanan TI maka kualitas TI pun akan meningkat.

b. Manajemen harus rutin dalam melakukan evaluasi dan monitoring pelaporan dan pelayanan agar hasil dan kekurnagna dapat terpantau dan dapat segera diperbaiki.

c. Review Perjanjian dan Kontrak telah dilakukan sesuai dengan prosedur.

\subsubsection{Key Performance Indicator (KPI) pada DS01}

Key Performance Indicator (KPI) yang harus dilaksanakan yaitu :

a. Peningkatan layanan opreasional kepada user secara kontinyu

b. Evaluasi dan monitoring pelayanan dan pelaporan dilakukan setiap 1 minggu

c. Review perjanjian dan kontrak setiap 1 minggu agar teknologi sistem informasi tetap update.

\subsubsection{Key Goal Indicator (KGI) pada DS01}

1. Aktifitas layanan pengadaan, pemeliharaan, perawatan serta peminjaman pada Sub Bagian Perlengkapan dan Perbekalan dapat memenuhi kebutuhan user hingga mencapai $95 \%$.

2. Meminimalisasikan kesalahan hingga 0\% dalam pembuatan pelaporan pengadaan, pemeliharaan, perawatan serta peminjaman pada Sub Bagian Perlengkapan dan Perbekalan.

3. Tidak ada lagi kendala dalam penggunaan sistem informasi pengadaan, pemeliharaan, perawatan serta peminjaman pada Sub Bagian Perlengkapan dan Perbekalan.

4. Ketepatan waktu penyampaian untuk setiap perjanjian pengadaan, pemeliharaan, perawatan serta peminjaman pada Sub Bagian Perlengkapan dan Perbekalan yang dibutuhkan. 


\subsubsection{Critical Success Factor (CSF) pada DS10}

Menetapkan masalah terpenting atau tindakan untuk Sub Bagian Perlengkapan dan Perbekalan pada BKKBN Provinsi ABCD untuk mencaai pengendalian proses TI. Merupakan kondisi-kondisi, kompetensi dan perilaku yang bersifat kritis terhadap keberhasilan pencapaian tujuan, yaitu :

a. Pendefinisian masalah dan akar permasalahan dapat segera dicarikan solusi

b. Identifikasi dan klasifikasi masalah telah menggunakan prosedur atau cara yang sesuai dengan kondisi yang ada.

c. Integrasi dan konfigurasi manajemen atas kejadian

\subsubsection{Key Performance Indicator (KPI) Pada DS10}

Key Performance Indicator (KPI) yang harus dilaksanakan yaitu :

a. Training/pelatihan untuk mengatasi masalah/problem yang sering dihadapi telah dilakukan secara rutin setia 3 (tiga) bulan.

b. Pencarian akar masalah telah dilakukan agar penyelesaian masalah tidak memberikan kesan berpihak.

c. Selalu dilakukan pengawasan penyelesaian masalah agar tidak berdampak negatif terhadap lingkungan.

d. Penyelesaian masalah diarahkan kepada kedua belah pihak dan tidak berkepanjangan.

\subsubsection{Key Goal Indicator (KGI) pada DS10}

a. Terdapat beberapa metode yang jelas dasar hukumnya dalam penyelesaian masalah.

b. Mengatasi masalah yang akan datang dengan prosedur yang telah disepakati oleh manajemen.

c. Mengatasi permasalahan dan kegiatan dengan cepat dan efisien.

d. Ketepatan waktu penyelesaian untuk setiap penyelesaian masalah yang dibutuhkan akan memberikan reaksi positif dari user.

\subsubsection{Critical Success Factor (CSF) pada DS12}

Menetapkan prosedur pengelolaan IT terhadap fasilitas yang ada untuk Sub Bagian Perlengkapan dan Perbekalan pada BKKBN Provinsi ABCD untuk mencapai pengelolaan proses TI. Merupakan kondisi-kondisi, kompetensi dan perilaku yang bersifat penting terhadap keberhasilan pencapaian tujuan yaitu :

a. Pengelolaan Keamanan fasilitas TI harus ditingkatkan, dengan menempati aset sesuai kebutuhan.

b. Manajemen harus rutin dalam melakukan evaluasi dan monitoring terhadap fasilitas yang ada.

c. Perlindungan aset terjamin dan gangguan faktor manusia dan lingkungan.

d. Fasiitas yang disiapkan diletakkan sesuai dengan kebutuhan.

\subsubsection{Key Performance Indicators (KPI) Pada DS12}

Key Performance Indicators yang harus dilaksanakan yaitu :

a. Adanya pemantauan penggunaan asset yang diberikan

b. Adanya pengawasan terhadap penggunaan fasilitas secara formal

c. Adanya evaluasi/monitoring rutin setiap akhir bulan atau minggu keempat agar kegunaan dan keberadaan fasilitas terjaga dari hal-hal yang merugikan manajemen BKKBN Provinsi ABCD.

\subsubsection{Key Goal Indicator (KGI) pada DS12}

a. Penggunaan asset yang ada telah dikontrol secara sistematis

b. Tidak ada lagi asset yang tidak masuk dalam pengawasan manajemen

c. Efisiensi biaya dari proses dan operasi yang telah dilakukan dengan menjaga dan mengoptimalisasikan fasilitas yang diberikan.

d. Menghasilkan pelaporan yang sesuai dengan standar yang ada, dan mencirikan fasilitas yang telah optimalkan dioptimalkan. 


\subsection{Strategi Peningkatan Kualitas Layanan Sistem Informasi Sub Bagian Perlengkapan dan Perbekalan}

Berdasarkan hasil maturity level pada tabel 4.1 dan 4.2, diketahui bahwa maturity level sistem informasi Sub Bagian Perlengkapan dan Perbekalan sebagian besar berada pada level 3 (defined process), sesuai dengan maturity level yang diharapkan yakni level 4 (managed and measurable). Agar keseluruhan proses TI mencapai level yang diharapkan, maka perlu dibuat strategi perbaikan di seluruh proses TI pada domain DS. Berikut ini adalah strategi kebijakan yang harus dilakukan oleh pihak manajemen BKKBN Provinsi ABCD berdasarkan Control Objective pada COBIT 4.1 agar tingkat kematangan yang diinginkan (Expected Maturity Level) dapat terdapai disertai dengan indiator pengukurannya.

1. DS1 Defined and Managed Service Level (menetapkan dan mengelola tingkat layanan)

Fokus utama pada DS1 yaitu mengidentifikasikan kebutuhuan layanan, membuat kesepakatan tingkat layanan servis serta mengawasi pencapaian mutu layanan.

Langkah yang harus dilakukan agar proses DS1 dapat mencapai maturity level 4 adalah sebagai berikut :

a. Membuat kerangka kerja untuk mendefinisikan layanan TI apa saja yang dibutuhkan dan disediakan bagi pelayanan kepada seluruh user.

b. Membuat buku panduan layanan

c. Membuat kesepakatan dengan pihak ketiga berupa service level aggrement (SLA) serta menetapkan Operating Level Agreement (OLA) untuk mendukung SLA.

d. Melakukan pengawasan, membuat laporan rutin terhadap kinerja layanan dalam bentuk formal.

e. Melakukan peninjauan terhadap kesepakatan dengan pihak ketiga serta memperbaharui SOP layanan.

f. Membuat rencana pengembangan layanan.
Berikut adalah beberapa indikator yang digunakan untuk mengukur pencapaian proses DS1 yaitu :
a. Besarnya prosentase tingkat kepuasan dari stakeholder bisnis yang menerima layanan.
b. Banyaknya jumlah layanan yang belum tersedia dalam prosedur layanan
c. Banyaknya pertemuan formal peninjauan SLA dnegan sasaran bisnis per semester.

\section{DS10 Manage Problems (mengelola masalah)}

Fokus utama proses DS10 adalah merekam, melacak dan menyelesaikan masalah operasional, menyelidik akar masalah bagi semua permasalahan yang ada, dan mendefinisikan penyelesaian bagi identifikasi masalah pengoperasian. Langkah yang harus dilakukan agar proses DS10 dapat mencapai maturity level 4 adalah sebagai berikut.

a. Mengidentifikasi masalah yang ada dan mengklasifikasi berdasarkan tingkat kerumitan masalah yang dihadapi.

b. Memeriksa status masalah, melakukan analisis terhadap akar permasalahan dan menyelesiakan masalah.

c. Mendokumentasikan permasalahan yang dihadapi, menginventarisir yang dapat diselesiakan atau yang belum dapat diselesaikan.

Berikut adalah beberapa indikator yang digunakan untuk mengukur pencapaian proses DS10 yaitu :

a. Banyaknya masalah yang mempunyai tingkat kesulitan yang berbeda dan dapat diselesaikan dengan prosedur dan pengambilan keputusan yang tepat.

b. Besarnya prosentase masalah yang diselesaikan sesuai dengan waktu yang ditentukan.

c. Frekuensi pelaporan masalah yang diselesaikan meningkat dan sangat membantu dalam mengurangi masalah. 
3. DS12 Managed the Pyhisical Environment (mengatur lingkungan fisik) Fokus utama proses DS12 adalah menyediakan dan memelihara infrastruktur TI dari akses, gangguan dan pencurian.

Langkah yang harus dilakukan agar proses DS12 dapat mencapai maturity level 4 adalah sebagai berikut :

a. Menentukan tingkat kebutuhan akan perlindunan infrastruktur

b. Memilih dan mengelola data, peralatan dan berbagai asset yang diberikan

c. Mendefinisikan dan menerapkan prosedur untuk otorisasi akses fisk serta pemeliharaan.

Berikut beberapa indikator yang digunakan untuk mengukur pencapaian proses DS12, yakni :

a. Banyaknya kejadian yang ada akibat kelalaian dan kurangnya pemeliharaan.

b. Banyaknya kejadian karena pelanggaran keamanan fisik.

Frekuensi penilaian dan peninjauan resikoresiko yang akan terjadi pada infrastruktur.

\section{SIMPULAN DAN SARAN}

\subsection{Simpulan}

1. Dari hasil penelitian diperoleh simpulan, proses DS1, DS10, dan DS12 pada Domain Delivery and Service yang diberikan oleh Sub Bagian Perlengkapan dan Perbekalan kepada BKKBN Provinsi ABCD secara umum berada pada tingkat kematangan defined process, yaitu terdapat bukti bahwa institusi mengetahui adanya permasalahan yang harus diatasi, dan telah diproses menggunakan metode yang telah distandarkan dalam penyelesaiannya, telah mendefinisikan dengan jelas langkah-langkah yang akan dipergunakan dalam menunjang pelayanan. Secara umum pendekatan kepada pengelolaan proses telah terorganisasi secara baik.
2. Acuan dalam sistem informasi Sub Bagian Perlengkapan dan Perbekalan pada BKKBN Provinsi ABCD yang diberikan oleh pelayanan dengan menggunakan kerangka kerja COBIT 4.1 adalah maturity level. Dari hasil kuesioner yang disebarkan terdapat expected maturity level di level managed and measurable pada level 4.

3. Gap yang ada baik itu tingkat user maupun manajemen tidak menunjukkan gap yang besar sehingga dapat diambil kesimpulan apa yang diharapkan oleh manajemen rata-rata sudah terpenuhi dan sistem sudah dijalankan.

4. Rekomendasi yang dapat peneliti ajukan adalah tambahkan domaindomain yang dinilai sehingga hasilnya akan menjadi lebih baik dari saat ini.

\subsection{Saran}

Hasil penelitian ini diharapkan dapat dijadikan salah satu referensi dalam sistem informasi TI secara lebih komprehensif. Penulis menyarankan BKKBN Provinsi $\mathrm{ABCD}$ harus meminta Sub Bagian Perlengkapan dan Perbekalan untuk melakukan perbaikan berikut ini :

1. BKKBN Provinsi ABCD harus melakukan analisa yang lebih mendalam mengenai kualitas layanan jasa yang telah dilakukan oleh Sub Bagian Perlengkapan dan Perbekalan dengan mengacu kepada framework COBIT 4.1.

2. BKKBN Provinsi ABCD harus melakukan perbaikan berdasarkan skala prioritas kepentingan tertinggi yang dapat mengganggu jalannya program BKKBN Provinsi ABCD untuk menghindari kerugian besar apabila terjadi gangguan yang diakibatkan oleh kualitas layanan Sub Bagian Perlengkapan dan Perbekalan.

3. BKKBN Provinsi ABCD harus menentukan target waktu kepada Sub Bagian Perlengkapan dan Perbekalan dalam melakukan perbaikan layanan.

4. Dapat dikembangkan untuk penelitian lebih lanjut dengan penambahan domain. 


\section{DAFTAR PUSTAKA}

Alexander Setiawan, Seminar Nasional Aplikasi Teknologi Informasi 2008, Evaluasi Penerapan Teknologi Infomrasi di Perguruan Tinggi Swasta dengan Menggunakan Model Cobit Framework, Yogyakarta. 2008/

Alvin A. Arens. James K. Loebbecke. Auditing. Edisi Indonesia. Jakarta. 2003

Ardi Hamzah, Seminar Nasional Aplikasi Teknologi Informasi, Tatalaksana Teknologi Informasi Metode COBIT, Yogyakarta. 2006

Devi Fitriasari dan Deny Arnos Kwary, Jurnal Sistem Informasi MTI-UI, Audit sistem Informasi dengan Kerangka Kerja COBIT untuk Evaluasi Manajemen Teknologi Informasi di Universitas XYZ. 2002

Fauzi Robby, Perencanaan Tatakelola Teknologi Informasi berdasakan framework COBIT (Studi Kasus pada Direktorat Metrologi), Sekolah Tinggi Manajemen Informatika dan Komputer (STMIK Bandung ), 2010

Gallegos Cs, Information System Control And Audit, The Institute of Cartered Accountants of India. 2000

Information System Audit and Control Asscociation (ISACA). IS Standards, Guideliness and Procedures for Auditing and Control Profesionals. 2003

IT Governance Institute. COBIT, Control Practices - Guidance to Achieve Control Objectives for Succesful IT Governance. Second Edition, USA.

Nina Ruliana, Evaluasi Peran Sstem Informasi Manajemen PT Mandala
Finance dengan menggunakan model Maturity Level pada Kerangka Kreja COBIT dan Domain Plan and Organise, Program Magister Sistem Informasi, Universitas Mercubuana, 2010

Pederiva A. The COBIT, Maturity Model in a Vendor Evaluation Case "Journal of Information System Audit. ISACA. USA. 2003

Romi Asku, Rancangan Tatakelola Teknologi Informasi untuk Pabrik Pupuk Information Research Group, Teknik Informatika, Sekolah Teknik Elektro dan Informasika - ITB, 2010

Sugiri. Evaluasi Peran Sistem Informasi Manajemen Koperasi Jasa Keuangan Syariah BMT Makmur Mandiri dengan menggunakan Model Maturity Level pada kerangka kerja COBIT pada Domain Plan and Organise, Universitas Gunadarma, 2010

Suhono Supangkat, Pengembangan Metode Pengukuran Sistem IT (Kasus : Perguruan Tinggi d Indonesia) Prosiding Konferensi Nasional Teknologi Infomrasi dan Komunikasi untuk Indonesia, Teknologi Bandung. 2006

Weber, Ron (1999), Information Systems Control and Auditing, The University of Queensland, Prentice Hall 